E51

.1392

vol. 9

no. 3

\title{
IINDIAN NOTES
}

\section{NMAIPEF.ND MONOGRAPHS}

EDITED By F. W. Hodge

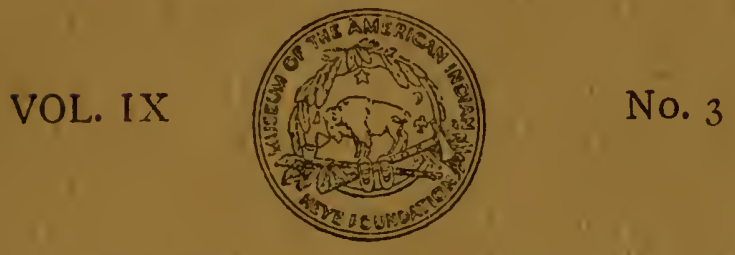

A SERIES OF PUBLICATIONS RELATING TO THE A.MERICAN ABORIGINES

\section{REPORTS ON THE MAYA INDIANS OF YUCATAN \\ $\mathrm{BY}$}

SANTIAGO MENDEZ, ANTONIO GARCÍA Y CUBAS, PEDRO SANCHEZ DE AGUILAR, AND

FRANCISCO HERNANDEZ.

EDITED BY

MARSHALL H. SAVILLE

NEW YORK

MUSEUM OF THE AMERICAN INDIAN

HEYE FOUNDATION 
ThIS series of INDIAN No'tes and MONOGRAPHS is devoted primarily to the publication of the results of studies by members of the staff of the Museum of the American Indian, Heye Foundation, and is uniform with Hispanic Notes and Monographs, published by the Hispanic Society of America, with which organization this Museum is in cordial coöperation.

Only the first ten volumes of INDIAN Notes and Monographs are numbered. The unnumbered parts may readily be determined by consulting the List of Publications issued as one of the series. 


\section{INDIAN NOTES \\ AND MONOGRAPHS}

Edited by F. W. Hodge

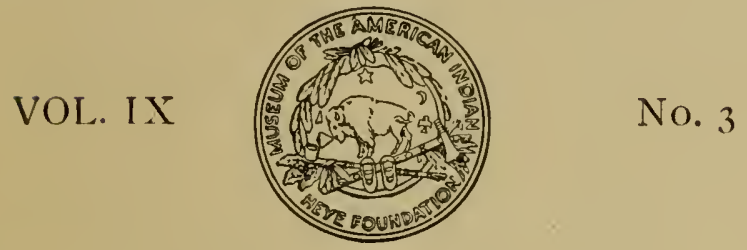

A SERIES OF PUBLICATIONS RELATING TO THE AMERICAN ABORIGINES

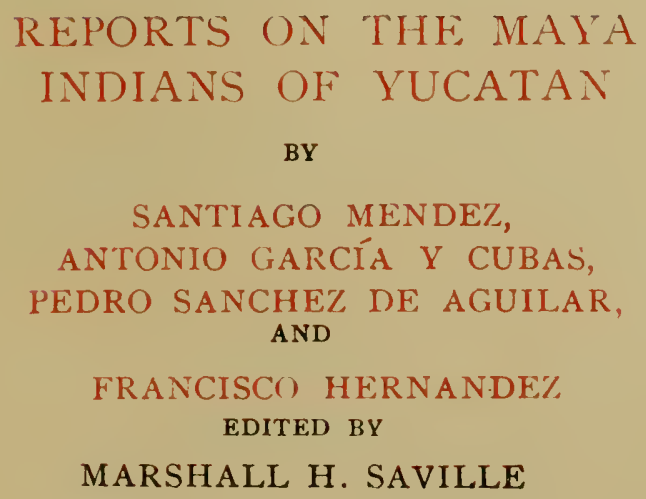





\title{
REPORTS ON THE MAYA INDIANS OF YUCATAN
}

\author{
BY \\ SANTIAGO MENDEZ \\ ANTONIO GARCÍA Y CUBAS, \\ PEDRO SANCHEZ DE AGUILAR \\ AND \\ FRANCISCO HERNANDEZ \\ EDITED BY \\ MARSHALL H. SAVILLE
}





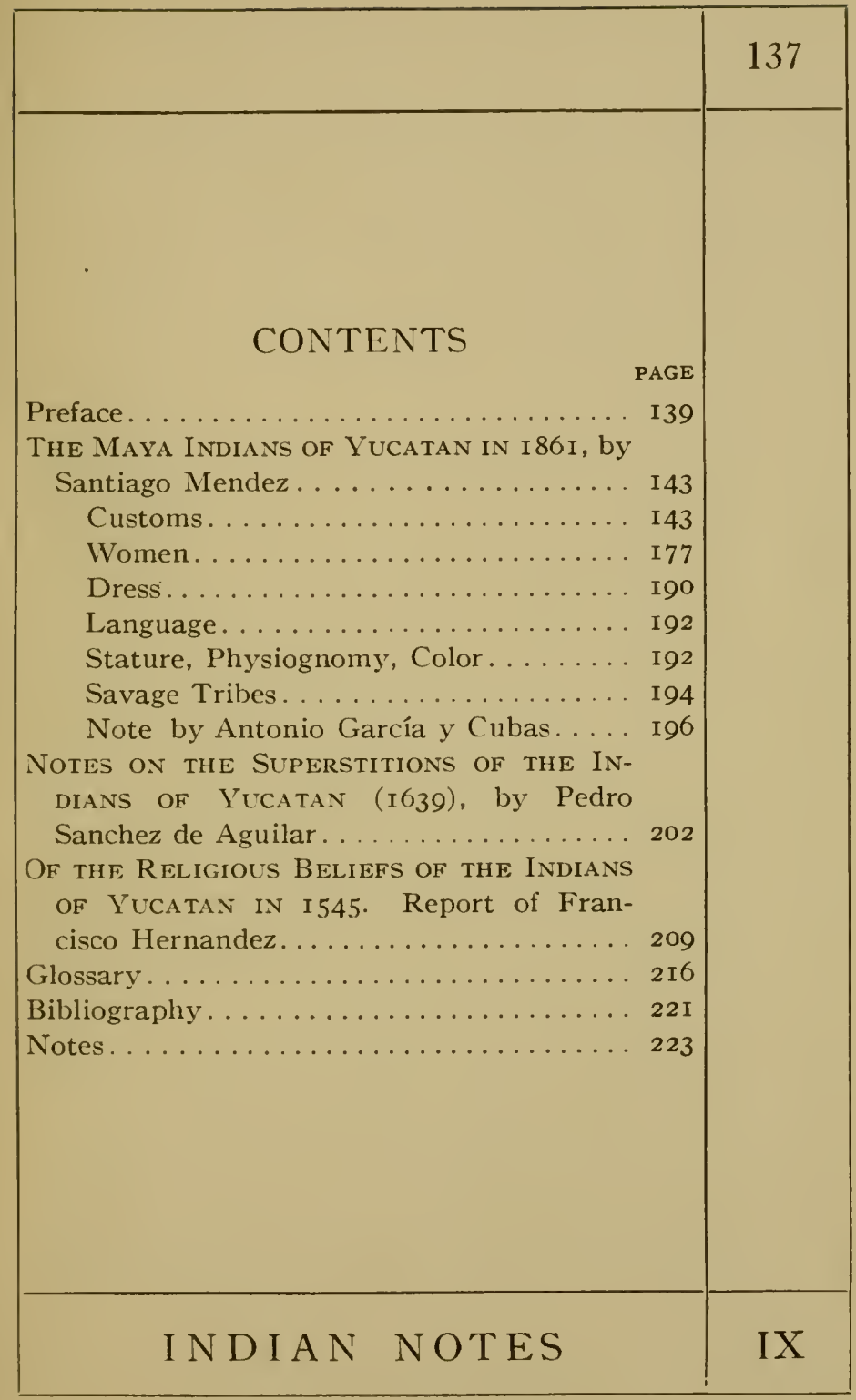





\section{PREFACE}

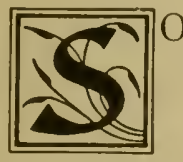

LITTLE has been written in regard to the ethnology of the Maya Indians of Yucatan, and especially concerning their beliefs, which persist to the present time, that we publish here a translation of an important and practically unknown account of this subject. This report was printed in Mexico in 1870 , but it is buried in a study by Antonio García y Cubas entitled "Materiales para formar la Estadistica General de la Republica Mexicana," in Boletin de la Sociedad Mexicana de Geografia y' Estadistica, segunda epoca, tomo II, pp. 352-388. It is on pages $374-387$, bears the date Mérida, October 24, I86I, and was written by Santiago Mendez, who states that he was governor of Yucatan during the years $\mathrm{I} 84 \mathrm{I}-42$. In connection with a

\section{NDIAN NOTES}




\begin{tabular}{|l|l|}
\hline 140 & \multicolumn{1}{|c|}{ M A Y A I N D I A NS } \\
\hline study of this report, so far as it relates to \\
the beliefs of the Maya, it will be profit- \\
able to consult the paper by Dr Daniel G. \\
Brinton on The Folk-lore of Yucatan, \\
printed in the Folk-Lore Journal, London, \\
vol. I, part viii, I 3 pp., August, I883. \\
We have also had translated the notes \\
on the superstitions of the Indians of \\
Yucatan contained in the work of Pedro \\
Sanchez de Aguilar, I639, published by \\
the Museo Nacional of Mexico in I892 \\
(pp. 83-84), and the report of Francisco \\
Hernandez on the religious beliefs of the \\
Yucatan Indians, which was sent to \\
Bartolomé de las Casas, evidently while \\
Bishop of Yucatan in I545, and is given by \\
him in chapter cxxiii (pp. 328-33o) of \\
his Apologetica Historia de las Indias, a \\
work which did not appear in print until \\
I875-76, the first complete edition of \\
which was edited by M. Serrano y Sanz, \\
and printed at Madrid in I 909. \\
The information contained in the \\
Mendez report is strikingly similar to \\
that given by Bartolomé José Granado \\
Baeza on Los Indios de Yucatan, an \\
\hline
\end{tabular}




\section{PREF A CE}

account written in 1813 but not published until 1845 , when it appeared in the Registro Yucateco, tomo I, Pp. I65-178. This report of Baeza is one of the principal sources used by Brinton in his study.

The editor has incorporated a few brief notes, and has prepared a glossary of the Indian words and a short bibliography of the subject.

Marshall H. Saville. 



\section{THE MAYA INDIANS OF YUCATAN IN I86I}

By Santiago Mendez

- Report on the Customs, Labor, Language, Industry, Phy'siognomy', etc., of the Indians of Yucatan, made by the Agent of the Department of Public Works, who signs this report, in obedience to orders of February 6, I86r.

\section{CUSTOMS}

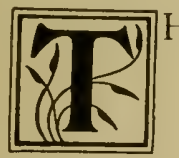

HE character of the Indians of Yucatan is such that, were they to be judged only by their customs and their habits, we would have to qualify them as stupid and devoid of reason. It seems indifferent to them to be in the shade or exposed to rain or to the scorching rays of the sun, even though they could avoid it. 


\begin{tabular}{|c|c|}
\hline 144 & M A Y A I NDIANS \\
\hline & $\begin{array}{l}\text { It does not matter to then whether they } \\
\text { go dressed or naked. They never try to } \\
\text { obtain commodities they see other races } \\
\text { enjoy, even though the trouble or sacri- } \\
\text { fice it would cost to get them might be } \\
\text { but small. In order to rest or to chat } \\
\text { with their companions they hardly ever } \\
\text { sit down: they squat, it being quite in- } \\
\text { different to them that they do it in a sun } \\
\text { that scorches them when they might per- } \\
\text { haps have shade two steps from where } \\
\text { they are. Reward does not encourage } \\
\text { them, nor does punishment admonish } \\
\text { them; in the first place, they think they } \\
\text { deserve more,- perhaps because they } \\
\text { were always accustomed to be made use } \\
\text { of,- and in the second case they con- } \\
\text { sider punishment as a kind of fatality } \\
\text { from which it is quite useless to try to } \\
\text { deliver themselves: hence they do not } \\
\text { reform. So long as their hunger is stilled, } \\
\text { it is quite indifferent to them whether } \\
\text { their meal is exquisite and varied, or } \\
\text { whether it consists only of tortillas and } \\
\text { chile, devouring their food in either case } \\
\text { with astounding voracity. IVhen they }\end{array}$ \\
\hline IX & I NDIAN NOTES \\
\hline
\end{tabular}




\begin{tabular}{|c|c|}
\hline MENDEZ REPORT & 145 \\
\hline $\begin{array}{l}\text { find themselves driven by utter necessity, } \\
\text { they will work in order to remedy it, } \\
\text { but they never do so with zeal or with } \\
\text { the desire to improve their fortunes. } \\
\text { They are so improvident that they may } \\
\text { squander in one day the earnings of a } \\
\text { week, in an exaggerated amount of dain- } \\
\text { ties or in superstitious practices, and } \\
\text { above all by intoxicating themselves, } \\
\text { leaving their families without bread and } \\
\text { clothing. Or, they remain idle until } \\
\text { whatever they earned by the sweat of } \\
\text { their brow is gone. They cultivate a } \\
\text { cornfield and gather a good harvest from } \\
\text { it, and even though they do not need } \\
\text { to do so, they will sell the corn with con- } \\
\text { siderable loss in order to squander the } \\
\text { money in splendid repasts and supersti- } \\
\text { tions, both of which always go together. } \\
\text { This harvest might insure the subsistence } \\
\text { of their family for a whole year, but their } \\
\text { improvidence will reduce them within a } \\
\text { few days to having to sell themselves for } \\
\text { work (peonage). } \\
\text { The love of the parents for their child- } \\
\text { ren, of the children for their parents, and }\end{array}$ & \\
\hline AND MONOGRAPHS & 3 \\
\hline
\end{tabular}




\begin{tabular}{|c|c|}
\hline 146 & MAYA INDIANS \\
\hline & $\begin{array}{l}\text { between husband and wife, is barely } \\
\text { lukewarm, and not at all passionate, if } \\
\text { we are to judge from their absolute lack } \\
\text { of signs of sympathy, pity, or condolence. } \\
\text { They contemplate dry-eyed and rather } \\
\text { indifferently the suffering of their nearest, } \\
\text { and even their demise, without allowing } \\
\text { this to change their demeanor or letting } \\
\text { it interfere in the least with their general } \\
\text { customs of life. } \\
\text { Although some of them can read and } \\
\text { write, they use it very little, either be- } \\
\text { cause they are very slow and clumsy in } \\
\text { the exercise of both, on account, no } \\
\text { doubt, of the lack of practice, and also } \\
\text { because there is but little written in their } \\
\text { own language. } \\
\text { Their children have usually no other } \\
\text { education than that which they receive } \\
\text { from the curates, priests, choirmasters, } \\
\text { and teachers of the catechism, which edu- } \\
\text { cation was formerly given to them at the } \\
\text { church doors or in the mansions of the } \\
\text { large ranches and farms, and they were } \\
\text { compelled to assemble every morning } \\
\text { from seven to eight to learn the cate- }\end{array}$ \\
\hline IX & I NDIAN NOTES \\
\hline
\end{tabular}




\section{MENDEZ REPORT}

chism. At the present day, as it is not possible to force the parents to send their children to learn even this, there are but few who learn at all, especially among the boys. When the writer of this was governor of this state in the years I84I and 1842 , he succeeded in establishing primary schools in almost all the villages, and although averse to anything that looks or sounds like despotism, he authorized, nevertheless, the mayors, justices of the peace, and chieftains (caciques ${ }^{1}$ ) to use it in order to force parents to send their children to the said schools. Unfortunately, in I 842 came the invasion by the forces of general Santa Anna, and in the effort to resist them, all the resources of the state were spent for many years in advance. Then followed our own senseless revolutions and the almost general uprising of these same Indians against the other native races, consequently these schools passed out of existence without it having been possible until this day to reëstablish them. Hence this remains an unsolved problem and it is difficult to

\section{AND MONOGRAPHS}




\begin{tabular}{|l|l|}
\hline 148 & \multicolumn{1}{|c|}{ M A Y A I N D A NS } \\
\hline $\begin{array}{l}\text { calculate the profit they might have } \\
\text { brought (once the tenacious and per- } \\
\text { sistent opposition of the Indians over- } \\
\text { come), leaving them convinced of the } \\
\text { advantages it might mean to further their } \\
\text { knowledge even in the manual labor they } \\
\text { perform. } \\
\text { Generally they train their children } \\
\text { from a very early age to help in their } \\
\text { agricultural labor such as their fore- } \\
\text { fathers did before the conquest, or else } \\
\text { they teach them light manual labor, such } \\
\text { as weaving little mats or matting in } \\
\text { general, making small bags, baskets of all } \\
\text { kinds and sizes, leather bands such as are } \\
\text { used by the native porters, sacks, ham- } \\
\text { mocks, ropes, to prepare henequen from } \\
\text { agave fiber, to make straw hats, and so } \\
\text { forth. In some villages they are taught } \\
\text { to make common pottery, and in places } \\
\text { near the coast they are shown how to } \\
\text { extract salt, to fish, and seamanship in } \\
\text { general. It is very rare that they are } \\
\text { taught other arts and crafts or trades, } \\
\text { with the exception perhaps in cities or } \\
\text { principal towns, where, especially when }\end{array}$ \\
\hline \multicolumn{1}{|c|}{ I N I A N N OT ES } \\
\hline I
\end{tabular}




\section{MENDEZ REPORT}

they have been reared and educated in the households of white people, they may become efficient in the art of quarrying stone, though quite primitively, or they qualify as masons, shoemakers, tailors, muleteers, drivers, and cowboys. They also provide the town with firewood, charcoal, and fodder.

With regard to their marriage customs, there is little else to say except that the daughter-in-law goes to live in the house of her father-in-law, and the son-in-law goes to live with his wife's parents, which is at present the most usual way, because an episcopal edict had to be issued prohibiting the first-mentioned to avoid the very frequent abuses committed on the bride by her father-in-law and brothersin-law. At a very early age young men marry, without repugnance, women who are much older, widows, and even girls who have children born out of wedlock. To remonstrances made by those who wish to dissuade them in view of such conditions, they will reply, "Why should I care? This happened before my time!"

\section{AND MONOGRAPHS}




\begin{tabular}{|c|c|}
\hline 150 & MAYA INDIANS \\
\hline & $\begin{array}{l}\text { It is to be supposed that conjugal fidelity } \\
\text { is not regarded very scrupulously by such } \\
\text { couples. Their most common diseases } \\
\text { depend largely on the seasons, and recur } \\
\text { regularly. During summer and fall, } \\
\text { when fresh food is abundant, the Indians } \\
\text { are very immoderate in its use, conse- } \\
\text { quently they suffer from diarrhea and } \\
\text { vomiting. In spring and summer they } \\
\text { have tabardillo, which is a burning fever, } \\
\text { and dysentery, both of which are caused } \\
\text { by too much exposure to the hot sun; } \\
\text { and in winter obstinate constipation, } \\
\text { colds, and affections of the throat and } \\
\text { lungs. Their curative methods consist } \\
\text { merely of abstinence and of blecding, } \\
\text { which they perform with a thorn or a } \\
\text { fish-bone, and they cool their blood by } \\
\text { drinking sour pozole or boiled lemonade, } \\
\text { or else a decoction of a plant called } \\
x h a n t u m b u \text {. They never use emetics nor } \\
\text { cathartics. } \\
\text { Ordinarily they eat two meals a day, } \\
\text { one on rising and another in the evening. } \\
\text { If they go to work in the field, after hav- } \\
\text { ing breakfasted on tortillas and atole, they }\end{array}$ \\
\hline IX & I NDIAN NOTES \\
\hline
\end{tabular}




\section{MENDEZ REPORT}

take with them a large lump of pozole which they use as a refreshment at noon by diluting it in water. At sunset they leave work, and, returning home, eat the second meal, generally after having taken their bath. Their usual food consists of boiled vegetables seasoned with salt, chile, and sometimes with the juice of oranges (the sour orange is used for this) or of lemons. On Sundays, if they are able to do so, they buy beef or pork; these are the only days when they eat meat, except when they kill a wild bird or a creature of the woods while hunting. Such meat they cook by baking it in a special way in the earth, or else in pib. The very poor among them live all the year round on tortillas and chile, and a bowlful of pozole or atole: Even the wealthiest content themselves with only one dish. This does not interfere with their being big eaters, nor devouring all they can get when it does not cost them anything.

Their usual beverage is called pitarrilia, consisting of the bark of a plant called

\section{A N D MONOGRAPHS}




\begin{tabular}{|c|c|}
\hline 152 & MAYA INDIANS \\
\hline & $\begin{array}{l}\text { balché which they put in soak in fresh } \\
\text { water and honey and let it ferment. } \\
\text { After fermentation it becomes strong } \\
\text { enough to be intoxicating. They are also } \\
\text { very fond of liquor, and there are very few } \\
\text { among them who do not become intoxi- } \\
\text { cated occasionally, at least on Sundays. } \\
\text { Experience, and to a certain extent } \\
\text { tradition, are their only guides for } \\
\text { telling the different seasons of the year; } \\
\text { they have not the slightest remembrance } \\
\text { of their ancient calendar system. They } \\
\text { are accustomed to hear clocks strike } \\
\text { where such exist, but otherwise, simply } \\
\text { from the course of the sun, moon, and } \\
\text { stars, they are able to regulate the hours } \\
\text { of the day and night, more or less. They } \\
\text { also know when an eclipse of the moon } \\
\text { is approaching, attributing this phe- } \\
\text { nomenon to an intention of the sun to } \\
\text { destroy his satellite, and they therefore } \\
\text { are prepared to make a fearful racket with } \\
\text { sticks, mitotes, whistles or horns (fotutos }{ }^{2} \text {, } \\
\text { shotguns, and other instruments during } \\
\text { the eclipse, believing that by so doing } \\
\text { they can avoid the catastrophe. }\end{array}$ \\
\hline IX & INDIAN NOTES \\
\hline
\end{tabular}




\section{MENDEZ REPORT}

They sleep from early evening until four oclock in the morning. Their working hours, if it is at all necessary for them to go to work, last from sunrise to sunset. If they are paid, they walk or travel at all hours, even with a load.

There are a few among them who are trustworthy and faithful in their contracts, and know how to keep their word and promises; but there is a greater number who absolutely lack all of these virtues, with the exception, perhaps, of the solemn promises they make to their saints, in the fulfilment of which they are scrupulously punctual.

They lie easily and very frequently, although they are aware that lies are prohibited. Generally they evade, whenever possible, a truthful answer which is to the point and fully satisfies the question.

Their principal vices are lasciviousness among both sexes, and drunkenness among the men. To do them justice though, we might as well acknowledge that it is more than probable that if other races and tribes had to live as they do,

\section{A ND MONOGRAPHS}




\begin{tabular}{|c|c|}
\hline 154 & MAYA INDIA NS \\
\hline & $\begin{array}{l}\text { almost naked, in the complete liberty } \\
\text { and isolation of country places, all mem- } \\
\text { bers of one family, males and females, } \\
\text { grownups and minors, the married and } \\
\text { the single ones sleeping together in those } \\
\text { little huts without any, or at best, very } \\
\text { scant, knowledge of religion, of modesty } \\
\text { and honor, without any fear of the conse- } \\
\text { quences of unchastity to the women, } \\
\text { without any intellectual enjoyment, re- } \\
\text { duced to the merest essentials-to satisfy } \\
\text { hunger, thirst, sleep, and the intercourse } \\
\text { of the two sexes, might they not be guilty } \\
\text { of worse crimes? } \\
\text { They are generally accused of being } \\
\text { inclined to theft, but as a rule they steal } \\
\text { small things of little value, and they are } \\
\text { not known to recur to violence or murder } \\
\text { to satisfy this tendency. } \\
\text { The wealthy are free money-lenders to } \\
\text { members of their own tribe and even to } \\
\text { those of a different stock, so long as they } \\
\text { are satisfied they are not going to be } \\
\text { cheated. } \\
\text { As in almost all of the most populated } \\
\text { part of the Yucatecan peninsula, it is }\end{array}$ \\
\hline $\mathrm{IX}$ & I NDIAN NOTES \\
\hline
\end{tabular}




\section{MENDEZ REPORT}

impossible to use the plow for tilling the fields; labor is reduced to clearing the tropical growth by burning it in the height of summer and sowing corn or vegetables when the rains commence, to fencing in the fields and weeding them, etc. In order to be able to cultivate at one time as much as possible of their extensive lands, the wealthy Indians pay their day-laborers and volunteers exceedingly well, either in money or in its equivalent in provisions at a price below its actual market value, especially in times of scarcity. They are guided in this by the rule, "This is sweat of my brethren and it is not right that they should pay it too dearly." If those workers are servants of some large ranch and live on the place, they are called Luneros, ${ }^{3}$ because they give their master their day's work on Mondays in exchange for the land he gives them to cultivate for themselves and for the water he allows them for irrigation of their fields. If they do not, for one reason or another, go to work on that day, he receives one 


\begin{tabular}{|l|l|}
\hline 156 & \multicolumn{1}{|c|}{ M A Y A I D I A N S } \\
\hline real in silver instead. The customary \\
amount of work they really are com- \\
pelled to do for their master per year is \\
twenty mecates of clearing of untilled \\
land and another twenty of already \\
previously tilled fields. Had the owner \\
to pay for hired labor, this would amount \\
to I2 pesos, 4 reals. In addition to this \\
they have to give him two hours on \\
Saturdays for what they call fagina, \\
which means work around the house of \\
any kind their patron should order them \\
to do. On some of the ranches the \\
obligatory field-work is reduced to half, \\
but in this case they have to pay their \\
real for Mondays, and always have to do \\
the Saturday's fagina. Any other service \\
or work they may be called on to do is \\
paid or put to their account. By milpa \\
roza ${ }^{5}$ the first clearing of a field by \\
felling trees, cutting and burning under- \\
growth, etc., is meant; while the milpa \\
cañ ${ }^{6}$ is the clearing of fields that have \\
already been tilled the year before, where \\
the cornstalks are to be split and burnt \\
in order to plant again. \\
\hline \multicolumn{1}{|c|}{ I N D I A N N O T ES } \\
\hline
\end{tabular}


Those who are employed as cowboys on stock-farms receive a fixed wage, and are not subject to the Monday service nor to the usual field-work. They have to look after the cattle and horses, and they have charge of the draw-wells, the tanks, and drinking pools. They have to attend to irrigation, weeding, and sowing of the truck gardens and orchards, and in general to do all work performed on such ranches either for their conservation and improvement or else in personal service to the owners or for the advantage of its products. It is also their duty to rasp a certain amount of henequen fiber from the agave each day. Their wage is from eight to twelve reals per month and five almudes ${ }^{7}$ of corn per week. Yet neither this latter nor the salary are paid to him as his earnings, but credited to his account against what he draws in provisions or money, so that he actually is always indebted. This, however, is the aim of the owners, in order to hold the man quite secure, even though they know very well that, should the man die

\section{AND MONOGRAPHS}




\begin{tabular}{|c|c|}
\hline 158 & MAYA INDIANS \\
\hline & $\begin{array}{l}\text { in their service, they would lose that } \\
\text { amount. They see to it, however, that } \\
\text { he never owes too much. This really } \\
\text { constitutes a kind of slavery (peonage) } \\
\text { which the men try to avenge by serving } \\
\text { as poorly as they can, even to such } \\
\text { masters as aim to make their lot easy } \\
\text { and agreeable by frequent gifts or } \\
\text { bonuses. } \\
\text { As a rule the Yucatecan Indians are } \\
\text { regarded as being meek, humble, and not } \\
\text { easily stirred to ire and cruelty, basing } \\
\text { such an opinion on the fact that the most } \\
\text { customary punishment among them was } \\
\text { a whipping applied with moderation. } \\
\text { This kind of punishment did not offend } \\
\text { them, if they were informed of the reason } \\
\text { why it was meted out to them, nor did } \\
\text { they consider it degrading. This char- } \\
\text { acteristic is still noticeable among those } \\
\text { who ho remained submissive and } \\
\text { attached to the white people. It is } \\
\text { quite different with those among them } \\
\text { who have had to suffer the cruel, atro- } \\
\text { cious, and protracted martyrdom in- } \\
\text { flicted by the rebels. They are merciless }\end{array}$ \\
\hline IX & I NDIAN NOTES \\
\hline
\end{tabular}




\section{MENDEZ REPORT}

to those who have fallen and still fall into their power, not only those of other tribes, but even of their own, in case they refuse to follow their tracks. They have no pity on either age or sex.

The chieftains (caçiques) of today, as well as those who were in office in the past, and the most prominent or wealthy Indians, live just as simply as the rest, without the slightest variation. They all are respected by their subordinates, whom they do not oppress to their own advantage, nor do they demand any services from them without compensation.

The Indians are generally gay, lighthearted, gossipy, and fond of tricks, in which they can display strength, agility, and adroitness. They are also very fond of music and song, although not very gifted or talented in the execution of the former especially. At their feasts and dances, which usually are rather tumultuous and poorly organized, they still use some of the old songs in their own language, to the accompaniment of a

\section{AND MONOGRAPHS}




\begin{tabular}{|c|c|}
\hline 160 & MAYA INDIANS \\
\hline & $\begin{array}{l}\text { little raucous flute, the carapace of a } \\
\text { turtle (hicotea), upon which they beat the } \\
\text { time with a hart's horn, and of the mitote } \\
\text { or taukul. The mitote }{ }^{8} \text { is a solid piece of } \\
\text { wood of cylindrical shape, one yard long } \\
\text { and a third of a yard or a little more in } \\
\text { diameter, open at one side almost from } \\
\text { one end to the other. This opening is } \\
\text { made for the purpose of hollowing out } \\
\text { the piece of wood until it is reduced to } \\
\text { one inch or a little more in thickness. } \\
\text { On the opposite side of the mouth, or } \\
\text { opening, they fasten two oblong wings, } \\
\text { which, starting at both ends, meet in the } \\
\text { center and are separated from one an- } \\
\text { other by a serrated edge. In order to } \\
\text { play this instrument, they place it, } \\
\text { mouth downward, on the ground, so } \\
\text { that the wings remain on the topmost } \\
\text { side, and they hit them with two short } \\
\text { sticks whose points are covered with an } \\
\text { elastic resin that makes them jump, so } \\
\text { as not to deaden or confound the sound, } \\
\text { which is of such resonance and force that } \\
\text { it may be heard. at a distance of two } \\
\text { leagues. }\end{array}$ \\
\hline IX & INDIAN NOTES \\
\hline
\end{tabular}




\begin{tabular}{|c|c|}
\hline MENDEZ REPORT & 161 \\
\hline $\begin{array}{l}\text { Notwithstanding the fact that they } \\
\text { regard death almost with indifference, } \\
\text { they are timid and cowardly. They never } \\
\text { attack the enemy unless they are far } \\
\text { superior in number. Still, they are very } \\
\text { astute or cunning to plan ambushes and } \\
\text { to take advantage of every occasion to } \\
\text { surprise their foes, and then fight with } \\
\text { great advantage, always accompanying } \\
\text { the fighting with frightful shouting. } \\
\text { They are gencrally good marksmen, and } \\
\text { they handle the machete with admirable } \\
\text { skill. IVenever they see that they can- } \\
\text { not resist the onslaught, they disperse in } \\
\text { the woods, but almost instantly come } \\
\text { together again at a previously designated } \\
\text { meeting-place. They are very fleet of } \\
\text { foot and good racers, and of an almost } \\
\text { incredible endurance for walking long } \\
\text { distances, even with a load of six to eight } \\
\text { arrobas [ } 5 \text { 5o to } 200 \text { pounds] }{ }^{10} \text { on their } \\
\text { backs. They also can stand a long time } \\
\text { without food or drink. } \\
\text { They do not excel in writing or in } \\
\text { learning to write, although not a few } \\
\text { have studied the same length of time and }\end{array}$ & \\
\hline AND MONOGRAPHS & 3 \\
\hline
\end{tabular}




\begin{tabular}{|c|c|}
\hline 162 & MAYA INDIANS \\
\hline & $\begin{array}{l}\text { the same subjects as white men, but they } \\
\text { are generally clownish and slow of under- } \\
\text { standing. It happens very often that } \\
\text { after they have been given a clear and } \\
\text { oft-repeated order, they will manage to } \\
\text { execute it the wrong way, and their } \\
\text { memory is so short that, although they } \\
\text { attend catechism daily from the age of } \\
\text { six or seven until they are twelve or four- } \\
\text { teen years of age, there are very many } \\
\text { among them who have never been able } \\
\text { either to learn it or to commit it to } \\
\text { memory. Those, however, who do not } \\
\text { cvade those lessons and who furthermore } \\
\text { attend the preaching of the gospel in } \\
\text { their own language, have obtained Cath- } \\
\text { olic ideas about eternity, the last judg- } \\
\text { ment, the glory of God, purgatory, and } \\
\text { hell. } \\
\text { As the climate of the peninsula is so } \\
\text { hot that it exhausts our physical strength } \\
\text { and energy, as well as reduces the needs } \\
\text { of man who can live almost nude and in } \\
\text { the open air and feed himself sparingly, } \\
\text { we cannot expect that the Indian should } \\
\text { be particularly inclined to work. Wle }\end{array}$ \\
\hline IX & I NDIAN NOTES \\
\hline
\end{tabular}




\begin{tabular}{|l|l|}
\hline M E N D E Z R E POR T & 163 \\
\hline had the same experience among the other \\
native races, although perhaps their \\
social standard may inpose greater \\
necessities. A hut of six or seven yards \\
in length by three or four in width, he \\
builds himself; its walls consist of rows \\
of sticks (which sometines are covered \\
with a coat of clay) and thatched with \\
palm-leaves or grass, with a door fre- \\
quently made of reeds twined together. \\
Two or three roughly-woven hammocks \\
of henequen, a machete, perchance a hoe, \\
perhaps a hatchet, and, very rarely, a \\
poor shotgun, are all his furniture. A \\
metate to grind his corn, an earthen pot \\
to boil it, another pot to cook the vege- \\
tables and the atole, a comal or flat \\
earthenware plate to cook the corn- \\
cakes or tortillas, a pitcher for water.. \\
one or two jicaras of gúero, ${ }^{11}$ an equal \\
number of gourds cut in halves to make \\
drinking vessels and for other purposes, \\
are the eating utensils. A roughly-made, \\
circular stool of half a yard in diameter \\
and about as much in height, and which \\
is used for shaping the tortillas as well
\end{tabular}




\begin{tabular}{|c|c|}
\hline 164 & MAYA INDIANS \\
\hline & $\begin{array}{l}\text { as for a table at which they eat their } \\
\text { meals, etc. Fifteen to twenty yards of } \\
\text { cotton cloth for the man's clothes, for the } \\
\text { wife's, and for the children's, which } \\
\text { costs a real per yard, supposing the } \\
\text { woman does not spin and weave this } \\
\text { herself; two or three coarse needles, a } \\
\text { reel of cotton thread, a straw hat, sandals, } \\
\text { a handkerchief and a cotton belt; a } \\
\text { large straw basket or hamper, a mecapal, } \\
\text { and a sack of henequen, complete the } \\
\text { list. A trough in which to wash clothes } \\
\text { and to bathe themsclves; a few pounds } \\
\text { of corn which he sows himself, as well as } \\
\text { chile, beans, calabazas, }{ }^{12} \text { camote [sweet } \\
\text { potatoes], and jicama, } 13 \text { a bunch of } \\
\text { bananas, the leaf of which is used to shape } \\
\text { the tortillas, and perhaps a sour orange. } \\
\text { His wood he himself cuts in the forest for } \\
\text { cooking his meals and also for the fire } \\
\text { which he keeps all night in the center of } \\
\text { the hut; and lastly a little salt. This is } \\
\text { the entire inventory of the necessaries of } \\
\text { life an Indian family of Yucatan needs, } \\
\text { and which suffices even to the wealthy } \\
\text { ones in the larger towns and principal }\end{array}$ \\
\hline IX & I N D I A NOTES \\
\hline
\end{tabular}




\section{MENDEZ REPORT}

cities. A great many of them live even without some of the things enumerated. They substitute for corn and vegetables (in case they cannot have them either for not having sown or for having lost the harvest), fruits, roots, and indigenous plants which grow wild all over their country, and which are edible and nourishing. Shall we still ask why the Yucatecan Indian is so indolent, when he has such few and such modest necessities, all of which are so easy to obtain even in the midst of the forests and at a great distance from any other human habitation?

He instinctively hates the superiority of the white race, and even of the mestizos, to whom institutions both of long ago and of the present day, customs, greater civilization, and above all the allotment of land, give so many advantages. His almost irresistible inclination carries him into isolation, almost exile, in order to escape from the torment of seeing them and from social duties. He retires where the land is free, where he can till his field wherever he pleases. 


\begin{tabular}{|c|c|}
\hline 166 & M A Y A I N D A NS \\
\hline & $\begin{array}{l}\text { This accounts for the often very small } \\
\text { settiements of perhaps only a couple of } \\
\text { families in the thickets of the forests, } \\
\text { provided they find a spring or at least a } \\
\text { watering place, even though they might } \\
\text { have to travel a considerable distance to } \\
\text { provide themselves. But even those who } \\
\text { live in larger settlements, in towns of } \\
\text { white people, will invariably select the } \\
\text { most retired spots in streets in the out- } \\
\text { skirts (far away from the center of the } \\
\text { town) where to build their huts. } \\
\text { This isolation in the big forests is the } \\
\text { principal cause of his beconing more and } \\
\text { more brutish, and it grows with the } \\
\text { facility which those same isolated places } \\
\text { afford him to satisfy the one and only } \\
\text { desire he has acquired-drunkenness. } \\
\text { It is there he finds balche and wild honey } \\
\text { to brew his pitarrilla. And there are } \\
\text { ever some of his own race or mestizos who } \\
\text { bring him liquor in exchange for the little } \\
\text { corn he may have stored. He gives this } \\
\text { up with an improvidence which seems } \\
\text { innate, though perhaps we might attri- } \\
\text { bute it to ignorance. }\end{array}$ \\
\hline IX & I NDIAN NOTES \\
\hline
\end{tabular}




\begin{tabular}{|c|c|}
\hline MENDEZ REPORT & 167 \\
\hline $\begin{array}{l}\text { The Indian never sees the crucifix or a } \\
\text { simple cross or the image of some saint } \\
\text { displayed anywhere, without going to } \\
\text { kneel before it in reverent devotion, nor } \\
\text { does he ever meet a priest without raising } \\
\text { his hat or hurrying to his side to kiss his } \\
\text { hand. He spends half of his earnings in } \\
\text { devotional offerings which in the end } \\
\text { degenerate into perfect orgies of religious } \\
\text { fervor. And yet, in spite of all that, he } \\
\text { does not feel the slightest scruple to take } \\
\text { as concubines his sisters or even his own } \\
\text { daughters. } \\
\text { He does not profess half as much love } \\
\text { and devotion to God as he shows toward } \\
\text { the images of Saint Anthony of Padua or } \\
\text { to the crucifix, both of which are the } \\
\text { only ornaments he has in his little hut. } \\
\text { He enters a church without bowing to } \\
\text { the Holy Sacrament on the main altar, } \\
\text { but he goes and kneels before the cross or } \\
\text { before Saint Anthony or Saint Francis } \\
\text { of Paula, or to any other image to which } \\
\text { miracles are ascribed, no matter how } \\
\text { poorly executed or how defective such an } \\
\text { image might be. On rising from his }\end{array}$ & \\
\hline AND MONOGRAPHS & 3 \\
\hline
\end{tabular}




\begin{tabular}{|c|c|}
\hline 168 & MAYA INDIANS \\
\hline & $\begin{array}{l}\text { prostrate position, he bends over to kiss } \\
\text { the altar, to touch its board with his } \\
\text { cheeks or forehead, then touches the } \\
\text { image itself, if such is possible, at least } \\
\text { with a twig of some aromatic herb or a } \\
\text { flower which he carries home as a relic, } \\
\text { paying it the utmost reverence. In addi- } \\
\text { tion to this he offers a certain amount of } \\
\text { money for candles which he lights before } \\
\text { the image of his saint at certain times; } \\
\text { he pays for a determinate number of } \\
\text { "Salve Reginas" to be sung either in the } \\
\text { church or during street processions for his } \\
\text { sake, and he offers prayers for the souls } \\
\text { of departed relatives. } \\
\text { He believes that the souls of the de- } \\
\text { parted return to earth, and he therefore } \\
\text { marks with chalk the road from the } \\
\text { cemetery to their former abode, that } \\
\text { they may not get lost. } \\
\text { He has just as deep-rooted a belief in } \\
\text { witches and elves, and he is in very great } \\
\text { fear of witchcraft. It is impossible toerad- } \\
\text { icate from his mind the idea that there } \\
\text { are men who especially dedicate them- } \\
\text { selves to inflict this dreadful art on others. }\end{array}$ \\
\hline IX & I NDIAN NOTES \\
\hline
\end{tabular}




\section{MENDEZ REPORT}

He fears and respects at the same time an ideal being whom he calls Balám and who, so he says, is the lord of the fields. They all are therefore convinced that these fields cannot be tilled without danger even to their lives if they do not offer him sacrifices before beginning work, such as horchata de maiz (orgeat), which they call sacá; a stew made of corn and turkey; which they call $\mathrm{kool}$; the tortilla with beans, called bulihuah; pitarrilla, and fumes of copal which they use instead of incense. It may safely be stated. therefore, that they adore him like God, but they are always careful that the white people do not see or notice this sacrificial offering for fear of being considered as idolators.

Alux they call certain apparitions which they believe to exist in the ancient ruins and on the hills, and they say that as soon as it grows dark in the evening these apparitions or ghosts commence to walk around the houses, throwing stones, whistling to the dogs and lashing them when they get near them, which leaves the

\section{AND MONOGRAPHS}




\begin{tabular}{|c|c|}
\hline 170 & MAYA INDIANS \\
\hline & $\begin{array}{l}\text { poor beasts with a cough that kills them. } \\
\text { They pretend that these ghosts can run } \\
\text { with great speed, as well backward as } \\
\text { forward; that they do not terrify those } \\
\text { who look at them. They are wont to } \\
\text { enter into the houses to annoy and tease } \\
\text { people who are abed in their hammocks, } \\
\text { not letting them sleep. They assure us } \\
\text { that on ranches where sugar-cane is } \\
\text { grown, and just as soon as the grinding } \\
\text { machine for the cane is set up, they will } \\
\text { go and turn it or they will drive on the } \\
\text { horse attached to it, to make it trot } \\
\text { around. They say these apparitions are } \\
\text { of the size of a little Indian boy of four } \\
\text { or five, and that they appear naked, } \\
\text { with only a little hat on their heads. } \\
\text { This belief is the cause of incalculable } \\
\text { loss to antiquarians on account of the } \\
\text { almost daily destruction of articles found } \\
\text { in the ruins. The Indians will destroy } \\
\text { without pity or regard, notwithstanding } \\
\text { they may be offered a good price for them, } \\
\text { all the images in clay and other objects } \\
\text { found on the hills or in subterranean } \\
\text { passages, because they are convinced }\end{array}$ \\
\hline IX & INDIAN NOTES \\
\hline
\end{tabular}




\begin{tabular}{|c|c|}
\hline MENDEZ REPORT & 171 \\
\hline $\begin{array}{l}\text { that these objects are the ones that be- } \\
\text { come alive at night and come out to walk } \\
\text { around. They attribute to the alux, or } \\
\text { to their influence, all the diseases they } \\
\text { have, as they consider their touch malig- } \\
\text { nant. They say that if these apparitions } \\
\text { find anyone asleep they will pass their } \\
\text { hands over his face so lightly that the } \\
\text { sleeper does not even feel it, but this } \\
\text { causes him a fever which incapacitates } \\
\text { him for a long time. } \\
\text { They also believe in the existence of } \\
\text { the Xtabay, the Hualuapach, and the } \\
\text { Xbolontharoch bokolhahoch. The first of } \\
\text { these apparitions or ghosts may be seen, } \\
\text { according to them, in the most isolated } \\
\text { spots of a village or settlement in the } \\
\text { shape of a woman dressed as a mestizo, } \\
\text { combing her beautiful hair with the fruit } \\
\text { of a plant they call xache xtabay. She } \\
\text { runs away as soon as anyone approaches. } \\
\text { She quickens or retards her flight, either } \\
\text { disappearing or allowing the one who } \\
\text { pursues her to reach her side. This } \\
\text { latter is the case if the one who pursues } \\
\text { her is some amorous fellow who thinks }\end{array}$ & \\
\hline AND MONOGRAPHS & 3 \\
\hline
\end{tabular}




\begin{tabular}{|c|c|}
\hline 172 & MAYA I NDIA NS \\
\hline & $\begin{array}{l}\text { her to be a beautiful maiden. But as soon } \\
\text { as he reaches and embraces her, he finds } \\
\text { that he holds in his arms a bundle filled } \\
\text { with thorns, with legs as thin as those of a } \\
\text { turkey, and this gives him such a terrible } \\
\text { shock that he has fainting spells and high } \\
\text { delirious fevers. The IIuahuapach is a } \\
\text { giant who may be seen at midnight in } \\
\text { certain streets, and he is so tall that an } \\
\text { ordinary man barely reaches to his knees. } \\
\text { He amuses himself by blocking the } \\
\text { traffic, opening his limbs and placing } \\
\text { one foot on either side of the street. } \\
\text { Should anyone inadvertently try to pass } \\
\text { between his feet, he quickly brings his } \\
\text { legs together and so closely presses the } \\
\text { throat of the poor victim that he finally } \\
\text { chokes him. The two other specters or } \\
\text { ghosts confine themselves to repeating } \\
\text { during the night the noises that have been } \\
\text { prevalent in the daytime, and especially } \\
\text { the noise made by the spindle-wheel the } \\
\text { women use. The other one makes a } \\
\text { subterranean noise which sounds like the } \\
\text { chocolate-churner, but both these noises } \\
\text { terrorize those who hear them. }\end{array}$ \\
\hline IX & INDIAN NOTES \\
\hline
\end{tabular}




\begin{tabular}{|c|c|}
\hline MENDEZ REPORT & 173 \\
\hline $\begin{array}{l}\text { There is no end of superstitions among } \\
\text { the general mass of the Indians, and the } \\
\text { most customary form of fortune-telling } \\
\text { is performed by means of a piece of a } \\
\text { certain crystal which they call zaztun, } \\
\text { which means a clear and transparent } \\
\text { stone, and this enables them to see hidden } \\
\text { things and also to divine the cause of } \\
\text { maladies. Those who arrogate to them- } \\
\text { selves the title of a diviner are freely } \\
\text { consulted, and they receive presents and } \\
\text { live a very easy and carefree life. By } \\
\text { means of their tricks and great cunning } \\
\text { they make the simple and ignorant } \\
\text { Indians believe, when they are ill and go } \\
\text { to consult them, that through the zaztun } \\
\text { they (the sorcerers) have discovered that } \\
\text { some ill-intentioned enemy has bewitched } \\
\text { them, and that in order to discover the } \\
\text { malicious spell, they will have to wake } \\
\text { for three nights with an abundant pro- } \\
\text { vision of pitarrilla, and aguardiente, food, } \\
\text { and lighted candles. Of course, during } \\
\text { these three nights they give themselves } \\
\text { up to high living and immoderate drink- } \\
\text { ing. While the others, their patients if }\end{array}$ & \\
\hline AND MONOGRAPHS & 3 \\
\hline
\end{tabular}




\begin{tabular}{|c|c|}
\hline 174 & MAYA INDIANS \\
\hline & $\begin{array}{l}\text { we may so call them, are sleeping, or } \\
\text { off their guard, they bury within the } \\
\text { house or in its immediate vicinity a little } \\
\text { wax figure pierced by a thorn through } \\
\text { that part of the body where the complaint } \\
\text { of their patient lies. When everybody is } \\
\text { awake after the last night of vigil, they } \\
\text { start certain ceremonies with the zaztun, } \\
\text { and finally they go to the spot where they } \\
\text { had buried the figure and take it out } \\
\text { within sight of everyone, making them } \\
\text { believe that that was the witchery. } \\
\text { Then they start their treatment of the } \\
\text { patient with the first and any herbs they } \\
\text { can find, and if by mere chance these } \\
\text { cure the ailment, they have naturally } \\
\text { made for themselves a great reputation } \\
\text { among the ignorant. } \\
\text { They also perform a "healing" in- } \\
\text { cantation by offering certain prayers in } \\
\text { which they mention the diseases and the } \\
\text { different winds to the influence of which } \\
\text { they attribute them. They will repeat } \\
\text { the Lord's prayer over their patient, the } \\
\text { Ave Maria, and the Creed, and sometimes } \\
\text { also the prayer to Saint Anthony which }\end{array}$ \\
\hline IX & I NDIAN NOTES \\
\hline
\end{tabular}


is included in the Mexican prayer-book. On other occasions they will resort to the kex, which means exchange, and consists in hanging around the house of their patient certain food and drink for the Yuncimil, or Lord of Death, and they believe that by so doing they are able to save, for the time being, the life of the patient by barter.

To prevent bees from abandoning the hives and to make them bring home ample honey, and also that their owners may be free from sickness, they will hang in the beehives chocolate cups with sacá or horchata of corn.

They also perform the misa milpera (mass on the cornfield), which they call tich, which means offering or sacrifice, and which is celebrated in the following manner: On a barbecue or roast made with little sticks of equal length they place a turkey, and the one who officiates as priest opens the bird's beak and pours pitarrilla down its throat. Then they kill it, and the assistants carry it off to season it. In the meantime they

A ND MONOGRAPHS 


\begin{tabular}{|c|c|}
\hline 176 & MAYA I NDIANS \\
\hline & $\begin{array}{l}\text { have been cooking in the earth some large } \\
\text { loaves of corn-bread which they call } \\
\text { canlahuntaz, which is made of fourteen } \\
\text { tortillas or broken bread filled with } \\
\text { beans. When all is well flavored and } \\
\text { cooked, they place it on the barbecue } \\
\text { with several cups filled with pitarrilla. } \\
\text { Now again the one acting the part of } \\
\text { priest begins to incense it with copal, in- } \\
\text { voking the Holy Trinity; he repeats the } \\
\text { Creed, and, taking some pitarrilla with a } \\
\text { holy-water sprinkler, he flings it to the } \\
\text { four winds, invoking the four Pahahtunes, } \\
\text { lords or custodians of rain. He then } \\
\text { returns to the table, and, raising one of } \\
\text { the jicaras aloft while those surrounding } \\
\text { him kneel, he places the jicara to each } \\
\text { one's mouth for a sip. The feast then } \\
\text { proceeds and terminates by general eat- } \\
\text { ing and drinking, most of all by the one } \\
\text { who "officiated," who furthermore takes } \\
\text { home with him a goodly supply. They } \\
\text { say that the red Pahahtun, who is seated } \\
\text { in the east, is Saint Dominick (Santo } \\
\text { Domingo); the white one in the north is } \\
\text { Saint Gabriel; the black one in the west }\end{array}$ \\
\hline IX & I NDIA N NOTES \\
\hline
\end{tabular}




\section{MENDEZ REPORT}

is Saint James; the yellow Pahahtun, said to be female and called by them Xanleox, is seated in the south, and is Mary Magdalen.

They very readily take their newborn babies to the baptismal font, and they never refuse to bury their dead in the cemetery.

\section{WOMEN}

It is quite astounding how in this climate woman in general passes very rapidly from childhood into womanhood, but this development is still more remarkable in the case of the native Indian woman, prompted no doubt by their mode of life and native customs. It is quite usual to see a little Indian girl of three trot daily to the woods with her parents to help cultivate the fields; very of ten her excursions extend to neighboring villages, and she seems to make those trips of four and even six leagues with the greatest ease, on foot; and after she has reached five or six years, she even carries her little bundle tied on her back.

\section{AND MONOGRAPHS}




\begin{tabular}{|c|c|}
\hline 178 & MAYA INDIANS \\
\hline & $\begin{array}{l}\text { They also journey day after day out } \\
\text { into the fields in search of firewood, small } \\
\text { sticks perhaps not thicker than an inch } \\
\text { or a little more, which they call moloch } \\
\text { They search for the wood themselves; } \\
\text { they cut it and tie it with two reed or } \\
\text { rattan rings, so that they can carry it } \\
\text { on their backs. Then they go for water } \\
\text { in the morning and again in the evening, } \\
\text { having to draw it from wells forty and } \\
\text { sixty yards deep, in buckets made of } \\
\text { tree-bark. After they have reached the } \\
\text { age of eleven or twelve years, they always } \\
\text { present themselves for this particular } \\
\text { errand, as clean as possible. They take } \\
\text { great care to be well-washed and their } \\
\text { hair carefully combed, almost as if they } \\
\text { were going for a pleasure walk or to some } \\
\text { meeting. This is particularly the case on } \\
\text { the ranches and farms, and in almost all } \\
\text { the villages where they have to provide } \\
\text { themselves with water from the com- } \\
\text { munal wells. } \\
\text { Between the ages of six and eleven } \\
\text { years the little Indian maiden attends, } \\
\text { either at the church door or, on big }\end{array}$ \\
\hline IX & I NDIAN NOTES \\
\hline
\end{tabular}




\begin{tabular}{|l|l|}
\hline M E N D E Z R E P O R T & 179 \\
\hline haciendas, in the main building, to the \\
teaching of our Christian religion. She \\
goes there with bare head and with her \\
hair hanging loose over her shoulders. \\
All a mother teaches her daughters is \\
how to cook, grind the corn, and shape \\
the tortillas; to make atole and pozole; \\
to wash clothes, and this very poorly,- \\
at all events. Or rather the girls learn \\
all those things by themselves through \\
mere observation and by helping their \\
mothers in their daily tasks Some \\
mothers, however, will teach them to \\
spin and weave their rough cotton cloth, \\
to sew their garments, and sometimes \\
even to embroider in a very primitive \\
way. \\
They are usually accompanied by a \\
criada, or housemaid, who is a kind of \\
guardian angel and remains by their side \\
wherever they go. When they meet the \\
man they love, they bow their heads and \\
look down; when speaking of their love, \\
with the big toe of one foot they will \\
draw lines on the ground. \\
While they are within their homes they \\
\hline A N D M O N O G R A P S
\end{tabular}




\begin{tabular}{|c|c|}
\hline 180 & MAYA INDIANS \\
\hline & $\begin{array}{l}\text { wear only a skirt or petticoat of white } \\
\text { cotton cloth, which covers them from the } \\
\text { waist down to their knees, and in this } \\
\text { way they will also present themselves to } \\
\text { visitors, unless it is someone absolutely } \\
\text { unknown to them, in which case they } \\
\text { cross their arms over their breasts to hidf } \\
\text { them from the stranger. If one meets } \\
\text { them in the fields or lies in wait for them } \\
\text { over the walls of unmortared stones, } \\
\text { they hide immediately, apparently to } \\
\text { run away from the presence of a way- } \\
\text { farer, notwithstanding they are all ex- } \\
\text { ceedingly curious, anci the love of gossip } \\
\text { is one of their main characteristics. } \\
\text { They are tender-hearted and desirous of } \\
\text { pleasing, but rather in an uncouth } \\
\text { manner, in keeping with what little edu- } \\
\text { cation they have received. Anyone who } \\
\text { asks them something in the name of God } \\
\text { is welcome to their compassion and to } \\
\text { whatever they can afford to give. } \\
\text { Their bodily cleanliness almost borders } \\
\text { on superstition, for they consider a } \\
\text { person who does not wash her body every } \\
\text { day as not quite sane or reasonable. For }\end{array}$ \\
\hline IX & I NDIAN NOTES \\
\hline
\end{tabular}




\begin{tabular}{l} 
M E N D E Z R E POR T \\
their daily bath they heat a stone they \\
call sintun in the fire, and when it is well \\
heated they throw it into the water they \\
have prepared for their bath. \\
It is very seldom that they are happy \\
in their love affairs, because it is gener- \\
ally their parents who choose their \\
husbands. After the choice is once made, \\
the parents of the prospective husband \\
come to ask for the girl's hand, and if \\
accepted they present an offering of two \\
pesetas, which is known under the name \\
of pochat tancab or buthul. One peseta \\
is for the bride-to-be, the other for her \\
mother. From the day following this \\
ceremony the bridegroom-elect has to \\
furnish daily a fagot of firewood to the \\
house of his future parents-in-law. On \\
her wedding day the bride is dressed in a \\
hipil or loose garment over a petticoat \\
or skirt, the border of which is adorned \\
with ribbons of deep purple; while \\
another wide ribbon of the same shade is \\
tied around her hair. Her head is cov- \\
ered with a cloth of white muslin. She \\
also has to wear shoes, a rosary around \\
\hline \\
A N D M O N O G R A P H S
\end{tabular}




\begin{tabular}{|c|c|}
\hline 182 & M A Y A I N D I A S \\
\hline & $\begin{array}{l}\text { her neck, earrings and fingerrings with } \\
\text { big cheap stones. All this jewelry may } \\
\text { be borrowed from someone. Once the } \\
\text { religious ceremonies over, they all pro- } \\
\text { ceed to the banquet, at which the newly } \\
\text { married couple and their godfathers } \\
\text { (sponsors) are assigned a prominent place. } \\
\text { If the girl is not to continue living with } \\
\text { her parents, she returns there, neverthe- } \\
\text { less, and remains for eight days, after } \\
\text { which time the godparents come to get } \\
\text { her and turn her over to her husband. } \\
\text { The husband is the recipient of all the } \\
\text { attention and care of his wife. She sews, } \\
\text { she washes, and she grinds the corn and } \\
\text { makes the tortillas, the pozole, the atole, } \\
\text { and all the rest of his food with her own } \\
\text { hands. She does all the work of her } \\
\text { household; she has to prepare his bath } \\
\text { when he comes home from work in the } \\
\text { evening. These are her. daily duties. } \\
\text { In the evening, by the light of the home } \\
\text { fire or in the pale light of a tropical } \\
\text { moon, she sews or mends his clothes and } \\
\text { hers and those of her children. When- } \\
\text { ever the husband leaves home to go on a }\end{array}$ \\
\hline IX & I NDIAN NOTES \\
\hline
\end{tabular}




\begin{tabular}{|c|c|}
\hline MENDEZ REPORT & 183 \\
\hline $\begin{array}{l}\text { journey to some neighboring town or } \\
\text { hacienda, the wife has to follow him; } \\
\text { she is never allowed, however, to walk by } \\
\text { his side, but behind, in his footsteps so to } \\
\text { speak. If this husband gets drunk, } \\
\text { which occurs rather frequently, and he } \\
\text { should fall by the roadside, it is the wife's } \\
\text { duty to remain by his side and take care } \\
\text { of him until he is able to continue on his } \\
\text { way. Neither the scorching sun, nor } \\
\text { heavy rains, nor thunderstorms, nor any' } \\
\text { other danger of the road has power } \\
\text { enough to take her away from his side. } \\
\text { Even the fact that a woman has just } \\
\text { been delivered of a child does not serve } \\
\text { as an impediment to her going with the } \\
\text { husband; she simply carries the new-born } \\
\text { baby with her, either in a piece of cloth } \\
\text { on her back or else mounted on one of } \\
\text { her hips. } \\
\text { If the husband, for one reason or } \\
\text { another, is called before a court of justice, } \\
\text { he appears accompanied by his wife, } \\
\text { simply because it is her duty to go with } \\
\text { him and to act as his defender. She } \\
\text { does this wonderfully well; she speaks }\end{array}$ & \\
\hline AND MONOGRAPHS & 3 \\
\hline
\end{tabular}




\begin{tabular}{|c|c|}
\hline 184 & MAYA INDIANS \\
\hline & $\begin{array}{l}\text { with such warmth and so fluently, with } \\
\text { such courage and enthusiasm, absolutely } \\
\text { free from her usual bashful shyness, that } \\
\text { one cannot help but admire her. And } \\
\text { this absolute devotion on her part to } \\
\text { the service of her consort does not weaken } \\
\text { even with the ill-treatment she receives } \\
\text { at his hands in return, for whenever he } \\
\text { is intoxicated he treats her to a liberal } \\
\text { whipping- he beats her with his bare } \\
\text { hands even, or with a stick. } \\
\text { Under such circumstances marital fidel- } \\
\text { ity on the part of the women is not, } \\
\text { nor can it be, very deep-rooted, and } \\
\text { frequently her seducers triumph over her } \\
\text { virtue. However, if the husband sur- } \\
\text { prises them and the woman succeeds in } \\
\text { escaping him, he denounces her to the } \\
\text { next court of justice and demands that } \\
\text { she be given a certain number of blows. } \\
\text { She invariably receives them quite re- } \\
\text { signedly, and after the ordeal returns } \\
\text { peacefully to her domestic duties. If the } \\
\text { woman is the offended one, she also goes } \\
\text { before the judge and demands that her } \\
\text { rival be treated to the same punishment. }\end{array}$ \\
\hline IX & INDIAN NOTES \\
\hline
\end{tabular}




\begin{tabular}{|l|l|}
\hline M E N D E Z R E P O R T & 185 \\
\hline Any sickness that might befall then after \\
this misadventure, they unfailingly attri- \\
bute to witchcraft instigated by their \\
offenders. Witchcraft enjoys such wide \\
popularity among Indian women that \\
there is hardly one anong them who \\
cannot relate one and even many cases \\
of the black art in her family. To their \\
minds superstition and credulity go hand \\
in hand, and if one tells them of some \\
strange occurrence ascribed to enchant- \\
ment, they believe it as readily and as \\
firmly as if it had happened to them- \\
selves or as if they had witnessed it. \\
And if one immediately afterward asks \\
them whether it is day or night, they \\
will answer doubtfully, even after having \\
looked at the sun-so wrapped up in the \\
tale have they become. \\
They are very fond of dancing and of \\
music, but they do not perform the \\
former either gracefully or freely, nor \\
have they any variety or art in its exe- \\
cution. They have no talent or gift for \\
playing an instrument either. They are \\
wont to sing in their idle moments or
\end{tabular}




\begin{tabular}{|c|c|}
\hline 186 & M A Y A I N I A NS \\
\hline & $\begin{array}{l}\text { even while at work, but sadly and in a } \\
\text { monotone. } \\
\text { The woman who finds herself pregnant } \\
\text { works until the very last moment before } \\
\text { the child is born, and resumes her tasks } \\
\text { immediately afterward, as soon as the } \\
\text { baby is attended to. They leave their } \\
\text { children so much to themselves, and give } \\
\text { them so little care, that they are forever } \\
\text { creeping around on the floor in all the } \\
\text { mire and dirt, and always completely } \\
\text { naked. A diaper and a tiny hipil are all } \\
\text { they get for the first few days of their } \\
\text { life. Around wrists and ankles they } \\
\text { occasionally will tie tiny cords made of } \\
\text { blue cotton to protect them, so they say, } \\
\text { from epilepsy. Those who can afford to } \\
\text { do so will hang a little rosary of beads } \\
\text { interspersed with wooden honey-berries } \\
\text { around their necks and put tiny earrings } \\
\text { in their ears. } \\
\text { A pregnant Indian woman will not go } \\
\text { outdoors during an eclipse, in order to } \\
\text { avoid her child being born with spots or } \\
\text { ugly birthmarks on its body; nor do they } \\
\text { visit women who have just given birth to }\end{array}$ \\
\hline $\mathrm{IX}$ & I NDIAN NOTES \\
\hline
\end{tabular}


a child, because it is their belief that the babies would become ill with pains in their bowels.

As soon as the child is six months old they name a godfather and a godmother for the ceremony of opening the baby's limbs for the first time. To this end they set a table with some kind of pottage, and the godfather makes nine rounds of the table, with the baby placed astride one of his hips, which is the way in which it will be carried thereafter by its mother. Then they place in the child's hands, if it is a girl, a needle, a spindle, and the implements with which they weave their cloth; if it is a boy, he is given a hatchet, a machete, and other implements he is expected to use when grown up. These godparents enjoy the same distinction as those at the christening.

The women do not care about knowing their own age, and they keep track of the age of their children only until they have attained about six or eight years; after that they forget it. Although they grow

\section{A ND MONOGRAPHS}




\begin{tabular}{|c|c|}
\hline 188 & MAYA INDIANS \\
\hline & $\begin{array}{l}\text { into young manhood or womanhood very } \\
\text { quickly, really old age comes late, except } \\
\text { in the appearance of the women, who at } \\
\text { the age of thirty-five look like women of } \\
\text { forty-five. } \\
\text { Their most common diseases are pleu- } \\
\text { risy, intermittent fevers, and jaundice, } \\
\text { while fits, fainting spells, and hysterics } \\
\text { are exceedingly rare. } \\
\text { As a rule the women are abstemious, } \\
\text { economical, and very hospitable. They } \\
\text { love work, and are fond of raising } \\
\text { chickens and turkeys, which they sell in } \\
\text { order to enable them to buy what they } \\
\text { most need, or else they prepare such fowl } \\
\text { for banquets, marriages, christenings, the } \\
\text { day of All Souls, or for the novenas which } \\
\text { they celebrate for the Holy Cross or the } \\
\text { saint of their special devotion. They do } \\
\text { not fancy all manner of necessities, nor } \\
\text { do they pretend to live on the work of } \\
\text { their husbands; rather they work con- } \\
\text { stantly in order to dominate them, and in } \\
\text { this they succeed generally, at least to a } \\
\text { certain degree. They will upbraid them } \\
\text { if they undertake anything without }\end{array}$ \\
\hline IX & I NDIAN NOTES \\
\hline
\end{tabular}




\begin{tabular}{|l|l|}
\hline M EN D E Z R E P O R T & 189 \\
\hline asking their advice. They do not forget \\
offenses they may have received until \\
they are avenged. In their old age they \\
are liable to commit small insignificant \\
thefts, and they especially seem to like \\
to become mendicants, even though they \\
do not need to be. They seem to do \\
this as a kind of compensation for what \\
in their earlier days they may have given \\
to the poor. \\
Sentiments of gratitude do not last \\
long. However, we must in this case \\
always except those who were reared in \\
the homes of white people. With few \\
exceptions (when perhaps poor methods \\
or little care in their education, or per- \\
chance bad example and ill-treatment \\
dominated), these Indian girls are virtu- \\
ous, assiduous, disinterested, and very \\
well-disposed toward all the different \\
branches of service and ready to learn \\
whatever they are taught. They are \\
modest, and are fond of dressing them- \\
selves nicely and decently. They are so \\
affectionate, true, and grateful, that \\
many a time they grow old in the service \\
\hline A N D M ONOG R A P HS
\end{tabular}




\begin{tabular}{|c|c|}
\hline 190 & MAYA INDIANS \\
\hline & $\begin{array}{l}\text { of one family, and if this family meets } \\
\text { with misfortune and perhaps becomes } \\
\text { impoverished, they will go to work out- } \\
\text { side to help support them, of which I } \\
\text { could mention many cases. Just the } \\
\text { opposite happens with the men, who, al- } \\
\text { though they were educated in a white } \\
\text { family from early childhood, and many a } \\
\text { time with the same care as the white } \\
\text { children, the cases are rare that they do } \\
\text { not gradually drift apart, become es- } \\
\text { tranged, give themselves up to vice, and } \\
\text { finally forget their benefactors entirely. } \\
\text { The ordinary costume of the men con- } \\
\text { sists of a shirt of white cotton like ours, } \\
\text { worn outside the white drawers of the } \\
\text { same material, which are wide and reach } \\
\text { to the calf of the leg; a belt, white or in } \\
\text { colors, is worn aroind the waist under } \\
\text { the shirt; a kerchief; a straw hat, and } \\
\text { sandals consisting of only soles which are } \\
\text { adjusted to the foot by cords of agave } \\
\text { fiber, complete his costume. While at } \\
\text { work in the field they take all their }\end{array}$ \\
\hline IX & I NDIAN NOTES \\
\hline
\end{tabular}




\section{MENDEZ REPORT}

clothes off and wear only a loin-cloth, which they call huit, consisting of a piece of cotton cloth fastened around the hips, the points passing between the thighs to be fastened to the belt below the navel. From this belt hangs the sheathed machete on the left side.

When they go out, the Indian women wear on their heads either a piece of cotton cloth of about half a yard in width by two and a half yards in length, the ends of which hang down the back, or else they tie a red kerchief around the head, a very bright red being their favorite color. A hipil of cotton is fashioned like a wide sacque-coat, with an opening in the center to put the head through, fitting around the neck, having openings on the two sides for the arms. This hipil reaches to about the calf of the leg, falling on a skirt or petticoat, also of white cotton, three or four fingers longer. It is fastened around the waist under the hipil, which falls loosely over it. The hem of both the skirt and the hipil are very often roughly embroidered in blue

\section{AND MONOGRAPHS}




\begin{tabular}{|c|c|}
\hline 192 & MAYA INDIANS \\
\hline & $\begin{array}{l}\text { or red thread. For traveling they wear } \\
\text { sandals like the men. } \\
\text { LANGUAGE } \\
\text { The Indians of Yucatan speak the } \\
\text { Maya language, though somewhat adul- } \\
\text { terated through contact with Spanish. } \\
\text { Several Spanish expressions have gradu- } \\
\text { ally crept into their idiom, especially in } \\
\text { cities and principal town where the } \\
\text { Indians are in almost constant intercourse } \\
\text { with whites and mestizos. Many among } \\
\text { them can speak Spanish perfectly well, } \\
\text { but as a rule they avoid it, and will } \\
\text { answer in Maya to those who speak } \\
\text { Spanish to them. } \\
\text { sTATURE, pHysIoGNOMY, coloR } \\
\text { Generally speaking, the Indians of } \\
\text { Yucatan are of about the same stature as } \\
\text { all intertropical races, of a round face, } \\
\text { straight black hair, rather coarse, not } \\
\text { very pronounced eyebrows, very little } \\
\text { beard or none at all, a low narrow fore- } \\
\text { head, black and expressive eyes, a some- } \\
\text { what flat nose, small but outstanding }\end{array}$ \\
\hline IX & I NDIAN NOTES \\
\hline
\end{tabular}




\section{MENDEZ REPORT}

ears, protruding cheekbones, a regular mouth with thin lips and beautiful teeth, a stout neck, broad chest and shoulders, arms, thighs, and limbs of robust and muscular build. Their hands and feet arc small, and the toes of their feet stand closer together than the heels. They have no hair on their bodies except on the head. Their color is a copper-brown, darkened through constant exposure to the sun, especially as they go about almost totally naked. The color of the women is therefore much lighter, and this is also the case with such men as have been reared from childhood in homes of the white people. Among the women there are some very pretty ones, slender in form, with an airy but graceful carriage, and a very sweet voice but the hard work to which they are subjected from early childhood causes them to lose their beauty at an early age. There are also some truly fine types among the men.

\section{AND MONOGRAPHS}




\begin{tabular}{|c|c|}
\hline 194 & MAYA INDIANS \\
\hline & $\begin{array}{l}\text { SAVAGE TRIBES } \\
\text { Of real savage tribes there are none in } \\
\text { Yucatan. After the greater part of the } \\
\text { peninsula, cities as well as villages, had } \\
\text { been reconquered from the possession of } \\
\text { the Indians who had taken them during } \\
\text { their insurrection in I } 847 \text {, which was } \\
\text { general, the most tenacious and unruly } \\
\text { ones among them settled in the eastern } \\
\text { part of the peninsula, where they have } \\
\text { built several towns, the principal one } \\
\text { being Chan-Santacruz. From these fast- } \\
\text { nessess they frequently sally forth to } \\
\text { attack and even to raze our absolutely } \\
\text { defenseless villages. These attacks cause } \\
\text { frightful suffering not only to members of } \\
\text { other tribes and races, without regard to } \\
\text { sex or age, but they are at times even } \\
\text { greater among those of their own race, } \\
\text { who at one time or another have either } \\
\text { absolutely refused to join their ranks, or, } \\
\text { after following their lead for some time, } \\
\text { have deserted, and returned to live in } \\
\text { peace among the white people. } \\
\text { Another and by far the most numerous }\end{array}$ \\
\hline IX & INDIAN NOTES \\
\hline
\end{tabular}




\section{MENDEZ REPORT}

band of those rebellious Indians went to settle in the south of the peninsula, and by virtue of the treaty they celebrated with General Vega have given up all hostilities, although they remain in complete independence of national as well as of state authorities, and in peaceful business intercourse with this city (Mérida), and also with Campeche and other points in close proximity to their abodes. Colonel Juan Sanchez Navarro drew a map, which he presented, together with his report, before the government of Yucatan on April 12 of the present year, on which map he gives an approximate idea of the localities on the peninsula still occupied by rebellious Indians who maintain a hostile attitude and those who have agreed to peaceful intercourse. The first mentioned he calls the eastern group, and the last named the southern one.

Sanitiago Mendez.

Mérida, October 24th, I86I.

\section{AND MONOGRAPHS}




\begin{tabular}{|c|c|}
\hline 196 & MA Y A I NDIA NS \\
\hline ' & $\begin{array}{l}\text { Note By ANTonio Garcí I Cubas } \\
\text { After having written about several } \\
\text { groups of aborigines who inhabit the } \\
\text { central part of the republic, I wish to } \\
\text { extend these notes with the aid of docu- } \\
\text { ments in my possession to the Indians of } \\
\text { Tabasco and Chiapas. } \\
\text { The customs, habits, and inclinations } \\
\text { of all those Indians in general do not, } \\
\text { with any certainty, evoke any hope for } \\
\text { the improvement of their race and their } \\
\text { subsequent utility and usefulncss to the } \\
\text { nation. The task I have set for myself } \\
\text { is a very delicate one, and there may } \\
\text { exist a great many people who will attri- } \\
\text { bute to lack of patriotism the frank state- } \\
\text { ment of many defects in our population; } \\
\text { but I observe that our nation is not mov- } \\
\text { ing toward its aggrandizenent with the } \\
\text { alacrity and speed which the progressives } \\
\text { among the authorities wish to see. } \\
\text { Therefore I consider it necessary to study } \\
\text { and point out the defects. I do not } \\
\text { wish it to appear as if the conceptions } \\
\text { expressed in these lines were imputations }\end{array}$ \\
\hline $\mathrm{IX}$ & I NDIAN NOTES \\
\hline
\end{tabular}




\section{GARCİA Y CUBAS}

of my own imagination, and I wish to state, therefore, that whatever is said in this report is extracted from official documents in my possession.

The aborigines living in the towns and villages of the district of Jalpa, and the same may be said of the rest of the Indians of Tabasco, despite their docility, prefer the wild, uncivilized life of the mountains to the advantages of communal life, if by so doing they are able to evade all public responsibilities and duties. They come together only for their religious festivities, and on all such occasions they are given to drunkenness and gluttony to such a degree that they contract very serious diseases which in a great many cases hasten their demise. With very few exceptions they live in complete vagrancy, and they propagate without respecting any degree of blood relationship. They insist on curing their diseases with all sorts of roots and plants, which, however, mostly impair their health, causing great mortality, especially among children. This may be

\section{AND MONOGRAPHS}




\begin{tabular}{|c|c|}
\hline 198 & MAYA INDIANS \\
\hline & $\begin{array}{l}\text { regarded as the principal cause why very } \\
\text { few among their number reach the age } \\
\text { of fifty years. } \\
\text { The aborigines who inhabit the borders } \\
\text { to the river Usumacinta and its tribu- } \\
\text { taries are for the greater part natives of } \\
\text { Yucatan, and are like all the rest of their } \\
\text { kind, very fond of drinking. The Indians } \\
\text { of Tenosique, about forty years ago, } \\
\text { were known as very honest and trust- } \\
\text { worthy, but their intercourse with the } \\
\text { rebels and emigrants from Iucatan have } \\
\text { demoralized them to a great extent. } \\
\text { These and other defects, with but a } \\
\text { few honorable exceptions, are revealed } \\
\text { in the documents treating of the Indians } \\
\text { of the district of Comitan, state of } \\
\text { Chiapas, which, however, I am not going } \\
\text { to enumerate, so as to avoid repetitions, } \\
\text { and by so doing make this article alto- } \\
\text { gether too long. } \\
\text { All the above mentioned shows the } \\
\text { decadence and general degeneration of } \\
\text { the aborigines, as compared with the } \\
\text { very scant elements of vitality and vigor } \\
\text { that might help in the movement toward }\end{array}$ \\
\hline IX & I NDIAN NOTES \\
\hline
\end{tabular}




\begin{tabular}{|l|l|}
\hline G A R C I A Y CUBAS & 199 \\
\hline progress in our republic. The same \\
customs, the same reserve and diffidence \\
which characterized the Indian of colonial \\
days is manifestly still his today under \\
the so-called protective laws of the re- \\
public, which barely give hin the title \\
of citizen. Yet, as I have stated before, \\
I do not belong to those who despair of \\
his ultimate civilization, and I believe \\
that the most efficacious means of \\
effecting this is by crossing his breed or \\
race by way of colonization, introducing \\
other nations and elements to come in \\
contact with him. \\
That this efficacious means of stopping \\
the infinite defects which retard, if they \\
do not hinder, the natural progress of our \\
nation, has not been attained, to my idea, \\
lies in the fact that so far no protective \\
laws have existed which, founded on pre- \\
vision, afford guaranties and procure \\
work for colonists. There are no laws \\
that fix the boundaries of the immense \\
stretches of waste-land within our coun- \\
try, nor a careful study of climate, ge- \\
ology, and production. There is not, to
\end{tabular} \mid




\begin{tabular}{|c|c|}
\hline 200 & MAYA INDIANS \\
\hline & $\begin{array}{l}\text { my knowledge, any report establishing } \\
\text { the best methods of making all our terri- } \\
\text { tory productive either through sales or } \\
\text { the renting of all lands that cannot be } \\
\text { tilled by their original owners. Our own } \\
\text { elements, as we have tried to demon- } \\
\text { strate in this article, are either hetero- } \\
\text { geneous or too scarce and insufficient to } \\
\text { accomplish the task of carrying the } \\
\text { nation onward on the road of aggrandize- } \\
\text { ment. Hence it is, according to my } \\
\text { idea, colonization, and colonization alone, } \\
\text { that may serve as the final remedy for } \\
\text { our national ills. } \\
\text { If we had today laws such as I have } \\
\text { had reference to, we would at this very } \\
\text { moment see European colonists arrive } \\
\text { continually, attracted by hopes of a } \\
\text { splendid future which our fertile soil and } \\
\text { our salubrious climate offer to the indus- } \\
\text { trious and enterprising man. Our popu- } \\
\text { lation would increase daily at the same } \\
\text { pace with the United States of Brazil and } \\
\text { Buenos Aires, where European immi- } \\
\text { gration forms an element of prosperity. } \\
\text { It remains for our government to fix in }\end{array}$ \\
\hline $\mathrm{IX}$ & I NDIAN NOTES \\
\hline
\end{tabular}




\section{GARCÍA Y CUBAS}

the most decisive way the answer to this question in the interest of the future of our country.

Antonio García y Cubas.

Mexico, May Ist, I87o. 


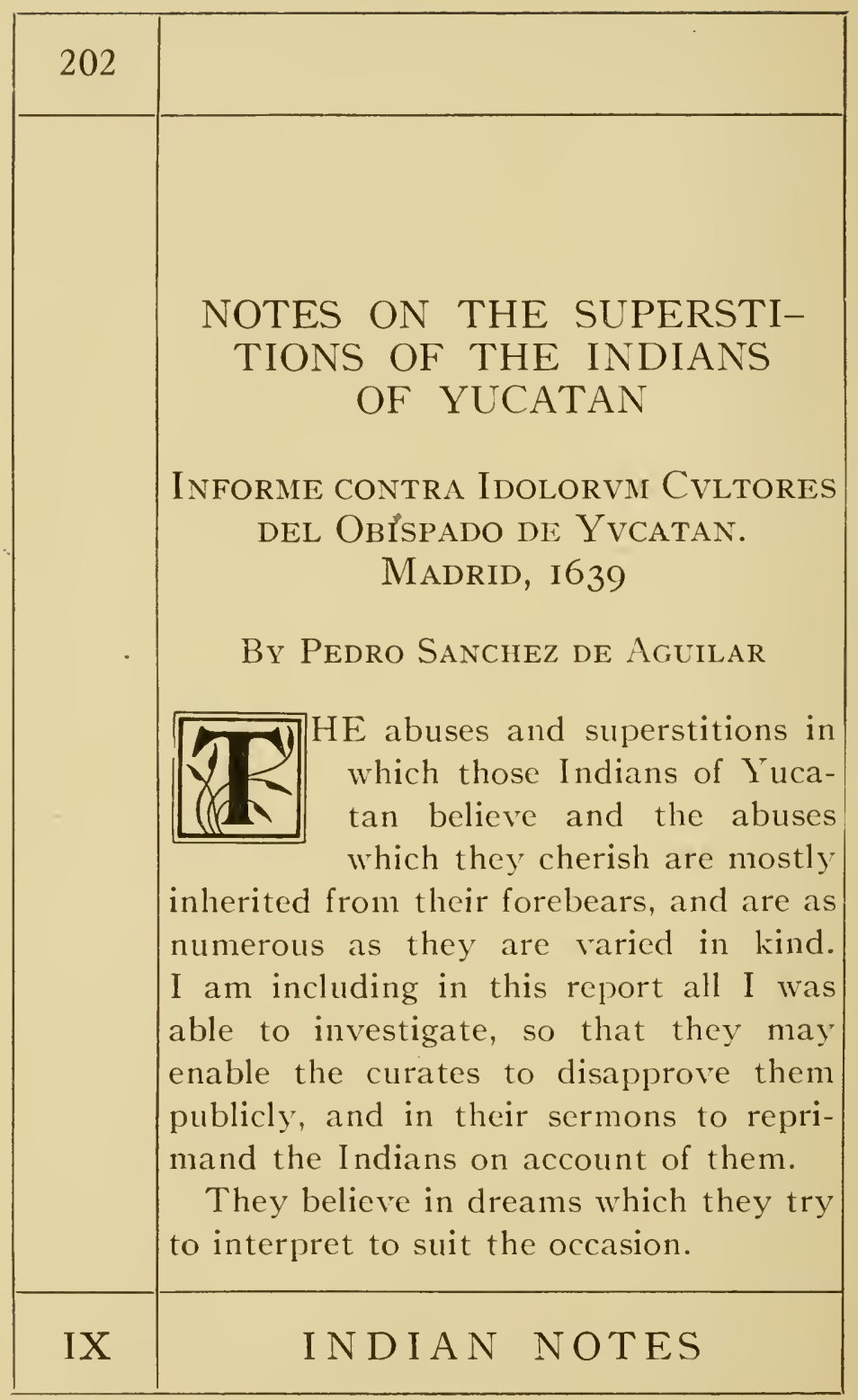




\section{SANCHEZ DE AGUILAR}

On hearing the cawing (or cackle) of a bird they call kipxosi, they interpret it to mean poor success to whatever enterprise they are engaged in at the time. They consider it as a bad omen or foreboding, as the Spaniards do with the female fox or the cuckoo.

If, while the Indian is traveling, he stumbles over a big stone among a pile which had been dug up to build or level a road, he renerates it by placing on the top of it a little twig, brushing his knees with another one in order not to get tired. This is a tradition of his forefathers.

If he happens to be traveling near sunset, and he fears that he will arrive late or even at night at the village he is bound for, he will drive a stone in to the first tree he finds, believing that this will retard the setting of the sun. Another superstition to the same effect is the pulling out of some of his eyelashes and blowing them toward the sun. These are superstitions that came down to him by tradition from his forebears.

During lunar eclipses they still believe

\section{AND MONOGRAPHS}




\begin{tabular}{|l|l|}
\hline \multicolumn{1}{|c}{ M A Y A I N D I A N S } \\
\hline $\begin{array}{l}\text { in the tradition of their forefathers to } \\
\text { make their dogs howl or cry by pinching } \\
\text { then either in the body or ears, or else } \\
\text { they will beat on boards, benches, and } \\
\text { doors. They say that the moon is dying, } \\
\text { or that it is being bitten by a certain } \\
\text { kind of ant which they call xubab. Once, } \\
\text { while at the village of Yalcobá, I heard } \\
\text { great noises during an eclipse of the } \\
\text { moon which occurred that night, and in } \\
\text { my sermon the next day I tried to make } \\
\text { them understand the cause of the eclipse } \\
\text { in their own language, according to the } \\
\text { interpretation from the Philosopher: } \\
\text { "The lunar eclipse is the interposing of } \\
\text { the earth between the sun and the moon } \\
\text { with the sun on top and the moon in the } \\
\text { shadow." With an orange to represent } \\
\text { the sphere of Sacrobosco, and two lit } \\
\text { candles on either side, I explained to } \\
\text { them plainly and at sight what an eclipse } \\
\text { really was. They seemed astonished, and } \\
\text { quite happy and smiling, curcd of their } \\
\text { ignorance and that of their forefathers. } \\
\text { I gave orders to their chieftain (caçique) } \\
\text { that he should punish in the future all }\end{array}$ \\
\hline \multicolumn{1}{|c|}{ I N D I A N N OT ES } \\
\hline
\end{tabular}




\section{SANCHEZ DE AGUILAR}

205

those who made a noise on such occasions.

They also call certain old Indian shamans when a woman is in labor, and, with words of their former idolatry, he will enchant her and hear her confession. They do the same with some other patients. I could not find out all about this, for which I am very sorry.

There are some Indian medicine-men who, with similar enchantment, are supposed to cure the bites or stings of snakes, especially of the rattlesnakes, of which there are a great many here. The victims of such bites are sometimes delirious, and often the flesh around the wound will decay until they die. The remedy the wizards give them, according to what I heard, is to make them eat human excrement or drink the juice of lemons, or else they will take a domestic fowl and place its beak on the wound, and have it suck in this way the poison of the snakebite. The hen or chicken will of course die, and they immediately replace it by another live one, and repeat that until all the poison is absorbed.

\section{AND MONGGRAPHS}




\begin{tabular}{|c|c|}
\hline 206 & MAYA INDIANS \\
\hline & $\begin{array}{l}\text { When they build new houses, which } \\
\text { occurs every ten or twelve years, they } \\
\text { will not inhabit nor even enter them } \\
\text { unless the old wizard has been brought } \\
\text { even from a distance of one, two, or three } \\
\text { leagues to bless it or consecrate it with } \\
\text { his stupid enchantment. This, however, } \\
\text { I have only heard, and I am now sorry } \\
\text { never to have recorded it personally. } \\
\text { They are fortune-tellers, and they per- } \\
\text { form this feat with a heap of grained corn, } \\
\text { counting always two and two grains, and } \\
\text { if it comes out in even numbers, the } \\
\text { fortune-teller will continue counting one, } \\
\text { two, or three times over until it comes out } \\
\text { uneven, bearing all the while in mind the } \\
\text { main facts or reason for which he had } \\
\text { been called on to tell the fortune, iera } \\
\text { gratia. Once a girl ran away from home, } \\
\text { and her mother, like any true Indian } \\
\text { woman would have done in a similar case, } \\
\text { immediately called one of those fortune- } \\
\text { tellers, who drew lots on all the different } \\
\text { roads until the fortune told of or pointed } \\
\text { to a certain road the girl had taken and } \\
\text { where she would be found. They sent }\end{array}$ \\
\hline $1 X$ & I NDIAN NOTES \\
\hline
\end{tabular}




\section{SANCHEZ DE AGUILAR}

out to look for her and found her in the village to which that road led. I punished that wizard, who was a native of a village at one league from Valladolid, and while I examined him with patience and slowly, I found that all the words he used in that so-called fortune-telling, while he counted the grains of corn, were no more than "Odd or even, odd or even" (huylan nones, caylan pares). He could not even tell me whether those words were meant as an invocation to Satan. In fact, he seemed not to know what they meant, for this particular wizard was a very great simpleton, almost imbecile.

In this city of Mérida it is publicly known that there exist several Indian sorceresses (witches), who by using certain words can open a rosebud before it is time for its opening, which is given to the one they wish to attract to their lascivious desire. They let him smell of it, or they place it under his pillow; but should the person who gives it to him smell its perfume, she is said invari-

\section{AND MONOGRAPHS}




\begin{tabular}{|c|c|}
\hline 208 & MAYA I NDIANS \\
\hline & $\begin{array}{l}\text { ably to lose her mind for a long while, } \\
\text { calling to the one she expected to inhale } \\
\text { it, and in whose name the rose was } \\
\text { opened by the witch-a worthy matter } \\
\text { which serves as medicine as well as } \\
\text { punishment, especially if it hits the double } \\
\text { mark. It has also been assured that the } \\
\text { Indian women of this city are wont to } \\
\text { throw a certain enchantment into the } \\
\text { chocolate which is ready for their hus- } \\
\text { bands to drink, and by it they become } \\
\text { bewildered. This I only heard however, } \\
\text { and I could not vouchsafe its truth. } \\
\text { I will also note here what I saw as a } \\
\text { child, and that is that they used to drown } \\
\text { in a hole young puppies of a breed of } \\
\text { dogs they raise as pets as well as for food. } \\
\text { These are a kind of dogs, with but little } \\
\text { or no hair at all, which they call tzomes. }{ }^{14} \\
\text { It is an old Jewish dogma of cosher. See } \\
\text { the Apostle, ut abstineant se a suffocatis, } \\
\text { etc. - that they abstain from the food of } \\
\text { animals dying by smothering or any kind } \\
\text { of natural death. }\end{array}$ \\
\hline IX & I NDIAN NOTES \\
\hline
\end{tabular}




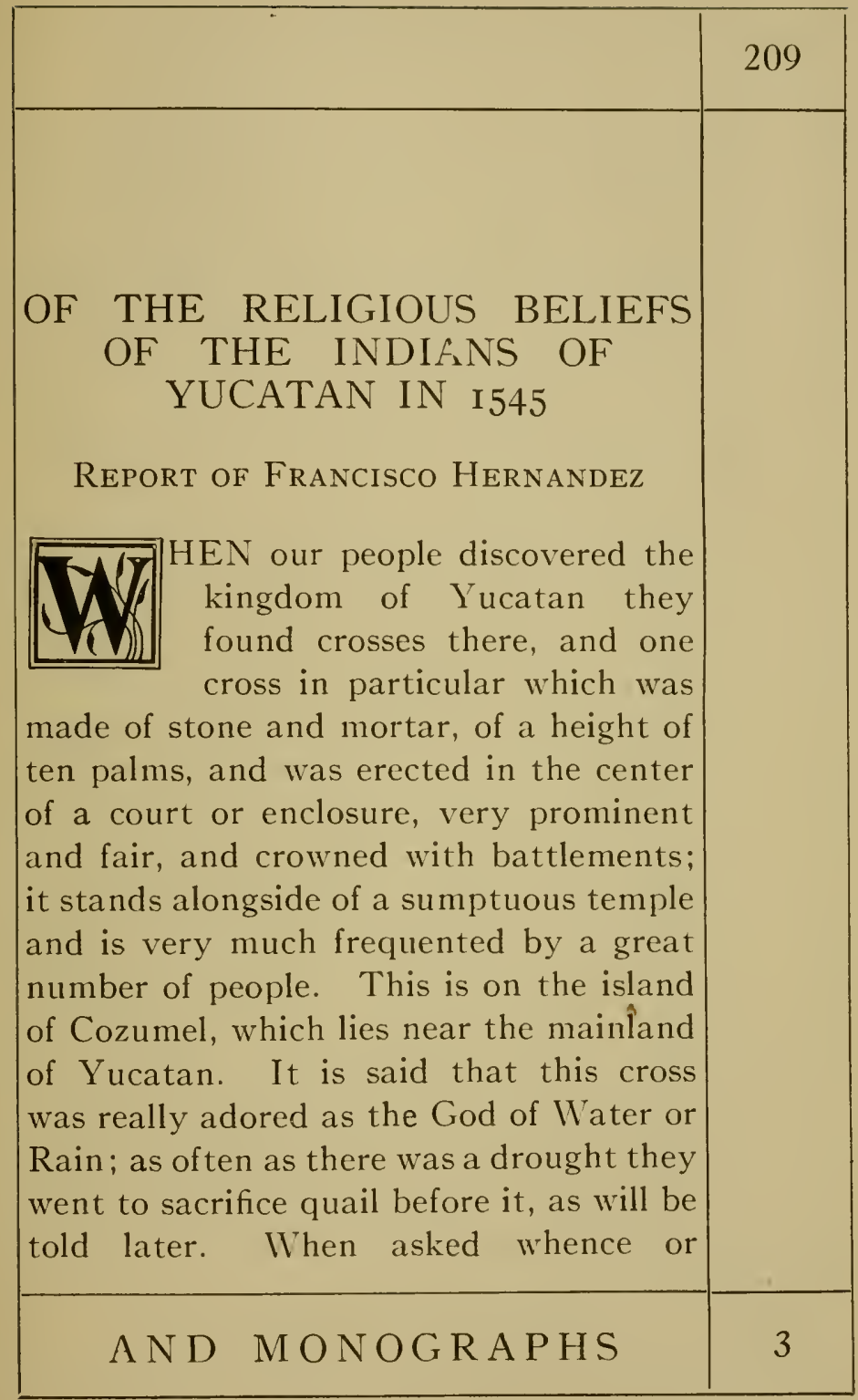




\begin{tabular}{|c|c|}
\hline 210 & MAYA I NDIANS \\
\hline & $\begin{array}{l}\text { through whom they had first heard of } \\
\text { that sign, they replied that a very hand- } \\
\text { some man had once passed through their } \\
\text { country and that he left it with them, } \\
\text { that they might always remember him } \\
\text { by it. Others, it is said, answered that } \\
\text { it was because a man more resplendent } \\
\text { than the sun had died on that cross. } \\
\text { This is referred to by Peter Martyr in } \\
\text { chapter I of his Fourth Decade. } \\
\text { I shall refer to another tale or report } \\
\text { which is very unusual and new regarding } \\
\text { the Indies, and which until now has not } \\
\text { been found in any other part of them. } \\
\text { As this kingdom, on account of its close } \\
\text { proximity to it, comes within the juris- } \\
\text { diction of my. bishopric of Chiapa, on } \\
\text { one of my visits I disembarked and re- } \\
\text { mained at a very healthy port. I met } \\
\text { there a clergyman, good, so it seemed, } \\
\text { of mature age and honest, and [one] who } \\
\text { knew the language of the natives from } \\
\text { having lived there several years. As it } \\
\text { was necessary for me to return to my } \\
\text { episcopal residence, I nominated him } \\
\text { as my vicar, and ordered and entreated }\end{array}$ \\
\hline IX & INDIAN NOTES \\
\hline
\end{tabular}




\section{F R A N C ISCO HER N A N D Z}

211

him to travel inland and visit the Indians there and preach to them in a certain way in which I instructed him. After a certain number of months (I even believe it was one year), he wrote to me that on his trip he had met a principal lord or chief, and that on inquiring of him concerning his faith and the ancient belief all over his realm, he answered him that they knew and believed in God who was in heaven; that that God was the Father, the Son, and the Holy Ghost. That the Father is called by them I çona, ${ }^{15}$ and that he had created man and all things. The Son's name was Bacab, ${ }^{16}$ who was born from a maiden who had ever remained a virgin, whose name was Chibirias, ${ }^{17}$ and who is in heaven with God. The Holy Ghost they called Echuac. ${ }^{18}$ They say that Içona means the great Father. Bacab, who is the son, they say killed Eopuco, ${ }^{19}$ and flagellated him, crowning him with a crown of thorns, and placed him with arms extended on a pole, not meaning that he should be nailed to it, but tied

\section{AND MONOGRAPHS}




\begin{tabular}{|l|l|}
\hline \multicolumn{1}{|c|}{ M A Y A I D I A N S } \\
\hline $\begin{array}{l}\text { (and in order to show him how, the } \\
\text { chief extended his own arms), where he } \\
\text { finally died. He was dead for three } \\
\text { days, but on the third day he returned to } \\
\text { life and went up to heaven, and he is } \\
\text { there with his Father. After this im-- } \\
\text { mediately came Echuac, which is the } \\
\text { Holy Ghost, and he filled the earth with } \\
\text { all it needs. Ihen asked what Bacab } \\
\text { or Bacabab meant, he said it meant the } \\
\text { son of the great Father, and that Echuac } \\
\text { meant merchant. And very good mer- } \\
\text { chandise did the Holy Ghost bring to } \\
\text { this earth, for he filled men with all their } \\
\text { faculties, and divine and abundant graces. } \\
\text { Chibirias means mother of the Son of } \\
\text { the great Father. He added, further- } \\
\text { more, that at a certain time all men would } \\
\text { have to die, but he did not seem to know } \\
\text { anything of the resurrection of the flesh. } \\
\text { When asked how they came to know all } \\
\text { these things, the chief replied that the } \\
\text { lords taught their sons, and in this } \\
\text { manner it. descended from one age to } \\
\text { another. They also assert that in olden } \\
\text { times, long ago, there came to the land }\end{array}$ \\
\hline \multicolumn{1}{|c|}{ I N D I A N N OT ES } \\
\hline
\end{tabular}




\section{F R A N C ISCO HER N A N E Z 213}

twenty men (he gave the names of fifteen of them), but because they were very poorly written, and furthermore as they do not have great importance for this report, I do not copy them. Of the five others the vicar says he could not obtain their names. The principal one was called Cocolcan, ${ }^{20}$ and they called this one the God of all kinds of fevers. Two of the others are the Gods of fish, still another two the Gods of farms and homesteads [landed properties], still another was the God of Lightning, etc. They all wore long gowns or mantles, and sandals for their feet. They had long beards, and wore nothing to cover their heads. These men ordained that the people should go to confession and should fast, and some people fasted on Fridays because on that day Bacab had died. The name of this day (Friday) is II imis, ${ }^{21}$ and they honor it in their devotion on account of the death of Bacab. The chiefs (caçiques) know all the particulars of those things, but the common people believe only in the three persons,

\section{AND MONOGRAPHS}




\begin{tabular}{|c|c|}
\hline 214 & M A Y A I N D I A NS \\
\hline & $\begin{array}{l}\text { Içona and Bacab and Echuac, and in } \\
\text { Chibirias, the mother of Bacab, and also } \\
\text { [in] the mother of Chibirias called Hisch- } \\
\text { en, }{ }^{22} \text { whom we consider to have been } \\
\text { Saint Ann. All this above stated is from } \\
\text { information I have received in a letter } \\
\text { from that reverend father whose name } \\
\text { is Francisco Hernandez, and I still have } \\
\text { his letter among my papers. He also } \\
\text { stated that he took the said chief to a } \\
\text { Franciscan friar who lived near there, } \\
\text { and that the caçique repeated all he said } \\
\text { before the friar, and they remained both } \\
\text { greatly surprised at it. If all those things } \\
\text { just stated are true, it would seem that } \\
\text { that part of the land had been (long ago) } \\
\text { informed about our Holy Faith, for in } \\
\text { no other part of the Indies have we ever } \\
\text { found such news. It is true that in } \\
\text { Brazil, which belongs to the Portuguese, } \\
\text { it was stated that traces of the wanderings } \\
\text { of Saint Thomas the Apostle had been } \\
\text { discovered, but such news could not very } \\
\text { well fly over through the air, and further- } \\
\text { more it is quite certain that the country } \\
\text { and kingdom of Yucatan give us more }\end{array}$ \\
\hline IX & INDIAN NOTES \\
\hline
\end{tabular}




\section{F R A NCISCO HER N A N DEZ 215}

special and singular cases to ponder over, and of far greater antiquity, if we think of the great, exquisite, and admirable way the most ancient buildings are constructed, also of a certain lettering in queer characters which are not found anywhere else. Finally these are the secrets which only God knows. 


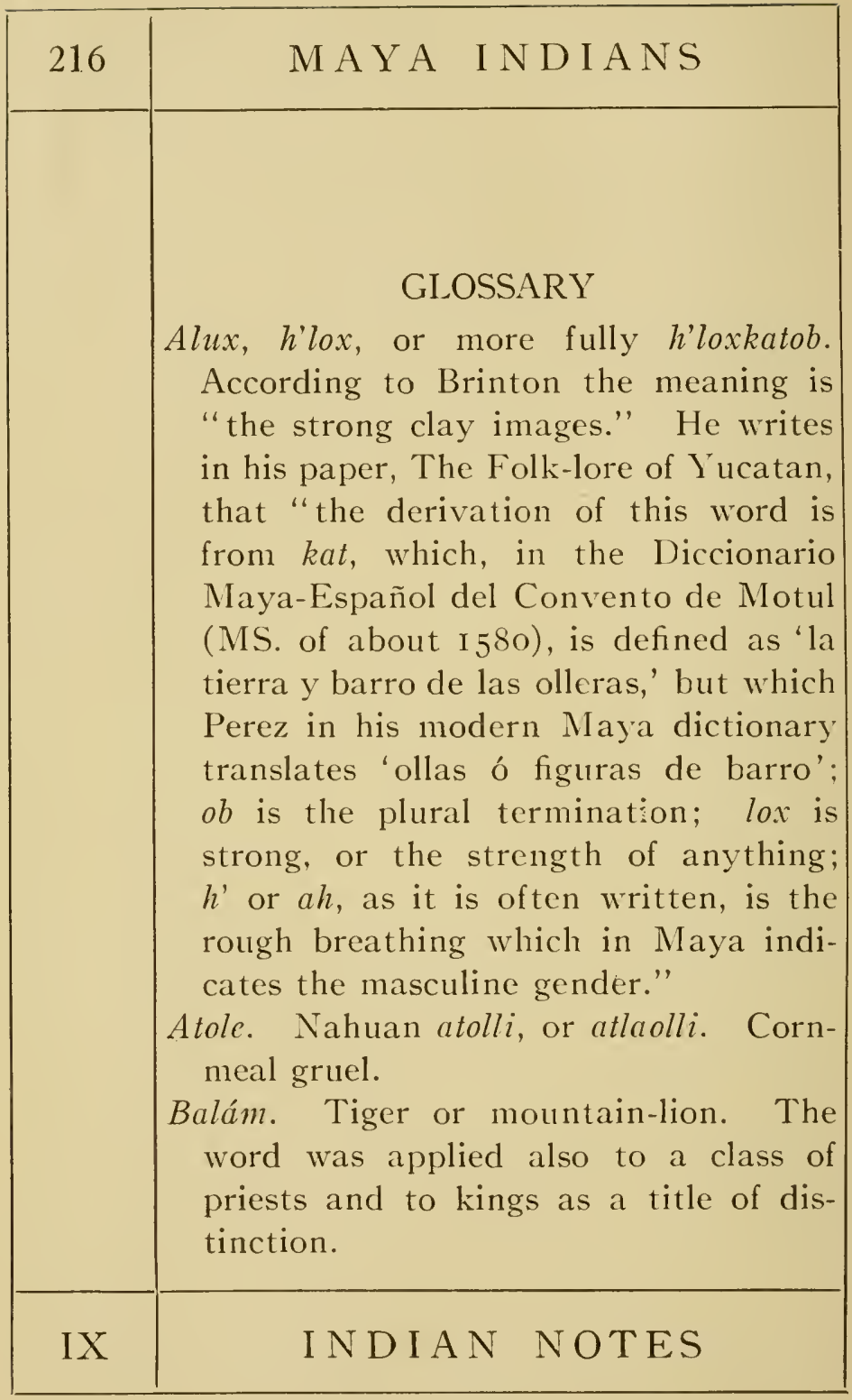




\begin{tabular}{|c|c|}
\hline GLOSSAR Y & 217 \\
\hline $\begin{array}{l}\text { Balché. A fermented liquor made from } \\
\text { wild honey and the bark of a tree. } \\
\text { Buhul, buuhul. A section of a stick of } \\
\text { wood split lengthwise in the middle. } \\
\text { Bulihuah. Tortillas made of corn-meal } \\
\text { and beans. From bul or butil, beans; } \\
\text { uah, tortilla. } \\
\text { Caçique. Antillean word meaning a lord } \\
\text { or chief. } \\
\text { Camote. Nahuan camotl, a kind of sweet- } \\
\text { potato. } \\
\text { Canlahuntaz. Large loaves of native } \\
\text { bread. From canlahun, fourteen; taz, } \\
\text { tiers, or layers. } \\
\text { Comal. Nahuan comalli, clay griddle. } \\
\text { IIipil. Nahuan huipilli, a woman's } \\
\text { chemise. } \\
\text { Huahuapach, ua ua pach. According to } \\
\text { Brinton (op. cit.) it means giant crab. } \\
\text { IIuit, uith. Loin-cloth. } \\
\text { Jicara. Nahuan xicalli, corrupted into } \\
\text { jicara, a calabash. } \\
\text { Kex. To barter or change; also used } \\
\text { as a name for ex votos placed on altars. } \\
\text { Kipxosi, kipchoh, cipchoh. "A diviner } \\
\text { bird among the Indians." }\end{array}$ & \\
\hline AND MONOGRAPHS & 3 \\
\hline
\end{tabular}




\begin{tabular}{|c|c|}
\hline 218 & MAYA I I D I A NS \\
\hline & $\begin{array}{l}\text { Kool. A dish prepared by cooking corn } \\
\text { with chicken. } \\
\text { Mecapal. Nahuan mecapalli, leathern } \\
\text { band used over the forehead for carry- } \\
\text { ing burdens. } \\
\text { Mecate. Nahuan mecatl, rope or cord } \\
\text { made of maguey fiber. } \\
\text { Metate. Nahuan metatl, a stone on which } \\
\text { corn is ground. } \\
\text { Milpa. Nahuan milli, cultivated land; } \\
\text { pan, a postposition. } \\
\text { Mitote. Nahuan mitotli, a dance. } \\
\text { Moloch. Brush-wood or kindling. } \\
\text { Pahatun, pah ah tun. The four pa ah } \\
\text { tunes, the lords of rains, are, according } \\
\text { to Brinton, "identical with the winds, } \\
\text { and the four cardinal points from which } \\
\text { they blow. . . The name pahatun is } \\
\text { of difficult derivation, but it probably } \\
\text { means 'stone, or pillar, set up or } \\
\text { erected.". } \\
\text { Pib. An underground oven. } \\
\text { Pochat tancab. According to the author } \\
\text { of this report the phrase has the same } \\
\text { signification as buhul: the offering made } \\
\text { to a girl by a prospective bridegroom. }\end{array}$ \\
\hline IX & INDIAN NOTES \\
\hline
\end{tabular}




\section{GLOSSAR Y}

The words seem to be: poc, to wash or rub; hat, numerical termination serving to count split-wood; tancab, outside the house, or in the patio.

Pozole. Nahuan pozolatl, or poçol atl, a drink of cooked corn.

Sacá, zacá. Orgeat of corn; from $z a$, corn gruel; cá, or caa, duplicative particle.

Sintun, zintun. A heated stone for heating water for bathing purposes. From zin, to haul, girdle or encircle; tun, stone. Taukul, tunkul. A wooden drum.

Tich. A mass celebrated in planted fields. See Brinton, op. cit.

Xaché xtabay. According to the author, the name of a plant. The first word, xaché, is evidently xach or xachah, to comb. Xtabay may be $x$-, a prefix, indicating feminine gender; tabal, to deceive.

Xanleox, $x$ kanleox. From $x$-, prefix denoting feminine gender: $k a n$, yellow; lox, to strike with the closed fist. Brinton simply gives "yellow goddess" as the equivalent. 


\begin{tabular}{|c|c|}
\hline 220 & MAYA INDIANS \\
\hline & $\begin{array}{l}\text { Xbolonthahroch bokolhahoch, } X \text { bolon thor- } \\
\text { och bokol (or bookol) h'otoch. From } x \text {-, } \\
\text { prefix denoting feminine gender; bolon, } \\
\text { nine; thoroch, sound of a spindle re- } \\
\text { volving in its shaft. Brinton says, } \\
\text { "The name therefore signifies "the } \\
\text { female imp who magnifies the sound of } \\
\text { the spindle.", Bokol or bookol, to stir; } \\
\text { hor ah, to indicate the rough breathing } \\
\text { which in Maya denotes the masculine } \\
\text { gender. } \\
\text { Xhantumbu, xkantumbub, or xkantun bub. } \\
\text { A small plant used for medicinal } \\
\text { purposes. } \\
\text { Xtabay. See etymology under xache } \\
\text { xtabay. } \\
\text { Xulab. Spelled by Sanchez de Aguilar } \\
\text { xubab. An ant which attacks bee- } \\
\text { hives. } \\
\text { Yuncimil, Yumcimil. The God of Death; } \\
\text { from yum, universal father or lord; } \\
\text { cimil, death. } \\
\text { Zastun. A quartz crystal; from zaz, } \\
\text { clear; tun, stone. }\end{array}$ \\
\hline IX & I NDIAN NOTES \\
\hline
\end{tabular}




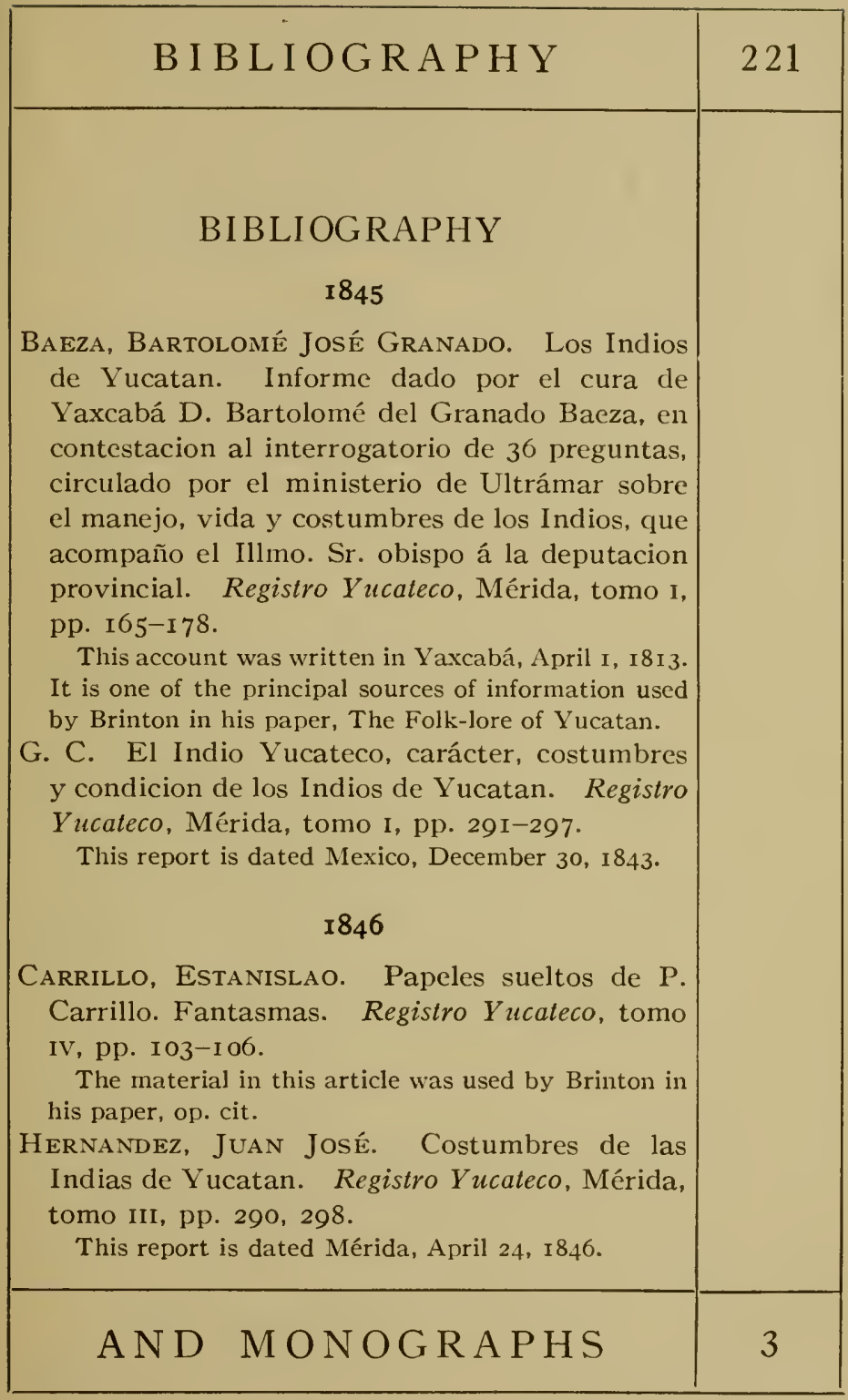




\begin{tabular}{|c|c|}
\hline 222 & MAYA I NDIA NS \\
\hline & 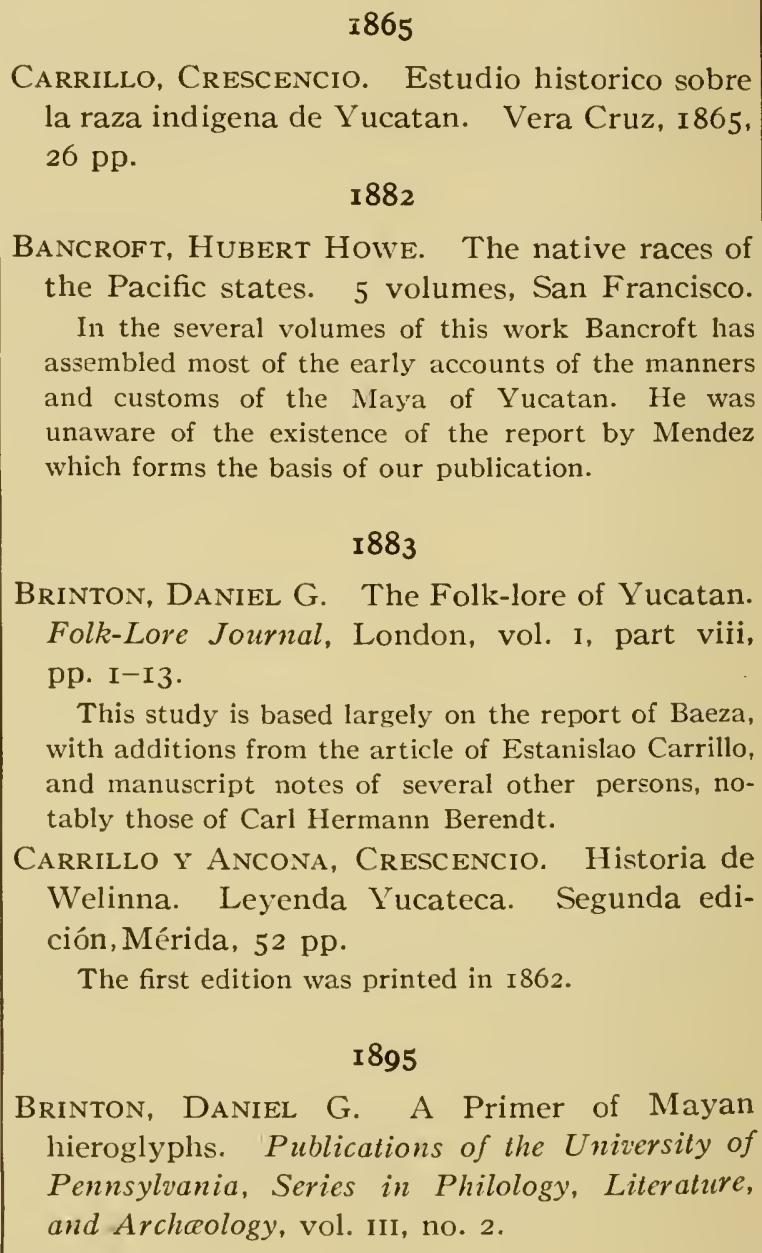 \\
\hline IX & I NDIAN NOTES \\
\hline
\end{tabular}




\begin{tabular}{|c|c|}
\hline NOTES & 223 \\
\hline $\begin{array}{l}\text { REJón GARCíA, MANUEL. Supersticiones y } \\
\text { leyendas Mayas. Mérida, I905. } \\
\text { NOTES } \\
\text { I. For the meaning of this and of other Indian } \\
\text { words, consult the glossary. } \\
\text { 2. Fotuto is a musical instrument used by the } \\
\text { Carib Indians and also by the negroes of the } \\
\text { Antilles. } \\
\text { 3. Luneros are Monday-workers. } \\
\text { 4. Fagina--faena, manual labor. } \\
\text { 5. Milpa roza is, literally, field cleared of } \\
\text { underbrush and ready for planting. } \\
\text { 6. Milpa caña, literally cane field. } \\
\text { 7. An almud is a dry measure equivalent to } \\
\text { twelve English bushels. There seems to be an } \\
\text { error in the quantity here. } \\
\text { 8. The author here seems to have confused the } \\
\text { meaning of the word mitote (see glossary). In } \\
\text { Yucatan the instrument he describes is called } \\
\text { tunkul. } \\
\text { 9. The machete is the large knife which the } \\
\text { Indian men of Yucatan invariably carry with } \\
\text { them. } \\
\text { I0. The arroba is the Spanish measure of } \\
\text { twenty-five pounds. } \\
\text { II. We have been unable to find the meaning } \\
\text { of the word güero. } \\
\text { I2. Calabaza is the Spanish for pumpkin; }\end{array}$ & \\
\hline AND MONOGRAPHS & 3 \\
\hline
\end{tabular}




\begin{tabular}{|c|c|}
\hline 224 & MAYA INDIANS \\
\hline & $\begin{array}{l}\text { but the Mexican pumpkin is different from that } \\
\text { raised in our latitudes. } \\
\text { I3. Jicama seems to be a local word not in the } \\
\text { dictionary. } \\
\text { I4. Tzomes, according to Sanchez de Aguilar, is } \\
\text { the name applied to hairless dogs. The common } \\
\text { appellation is kukbil, or kikbil. Tzom in Maya } \\
\text { means a horn, also a proboscis. The word } \\
\text { tzomes is close to tzimin, pl. tzimines, the name } \\
\text { of the tapir, which has an elongate snout. Alonzo } \\
\text { Ponce who was in Yucatan in I } 588 \text {, spealss of } \\
\text { tapirs being called by the natives tzimines, and } \\
\text { further states that they call horses by the same } \\
\text { name, a definition to be found in the Maya } \\
\text { dictionary of Pio Perez. } \\
\text { I5. The names to which we call attention in } \\
\text { notes I } 5 \text { to } 22 \text { represent, with a single exception, } \\
\text { in misspelled form, well-known Mayan deities. } \\
\text { It is interesting to note the carly influence of the } \\
\text { Spaniards on the religious beliefs of the Maya, as } \\
\text { evidenced by the interpretation given to Father } \\
\text { Hernandez by the old caçique. There is a } \\
\text { curious mixture of old and new in the account. } \\
\text { Dr Seler has identified the various deities spoken } \\
\text { of, and a description of their attributes will be } \\
\text { found in Brinton's Primer of Mayan Hieroglyphs. } \\
\text { Içona is Itzamna, chief of the benieficent gods, the } \\
\text { personification of the East. According to Brinton } \\
\text { the name means "the dew or moisture of the } \\
\text { morning." Brinton writes, "He was said to have } \\
\text { been the creator of men, animals, and plants, }\end{array}$ \\
\hline $1 \Omega$ & I NDIAN NOTES \\
\hline
\end{tabular}




\section{NOTES}

and was the founder of the culture of the Mayas. He was the first priest of their religion, and invented writing and books."

I6. According to Brinton the Bacabs, or Chacs, were the offspring of Itzamna and his consort Ix-Chel (spoken of by the caçique as Hischen).

I7. Chibirias is identified by Seler as $I x$-chebelyax, who, according to Brinton, was "the inventress of painting and of colored designs on woven stuffs."

I8. Echuac is Ek Chua, said by Landa to be the god of the cacao planters, hence, as cacaobeans were the medium of exchange, the god of merchants, as here related. It is difficult to understand the confusion by which this god has been interwoven in Christian beliefs as the Holy Ghost.

19. Eopuco has been interpreted by Seler as Ah uoh puc, or Ah-puch, the God of Death, or God of Evil. Brinton believes that "these words mean the Undoer, or Spoiler, apparently a euphemism to avoid pronouncing a name of evil omen." In modern Maya he is plain Yum cimil, lord of death.

20. Cocolcan is Cuculcan, or Kukulcan, the same as the Nahuan Quetzalcoatl. Kukulcan was the feathered or winged serpent god, a deity of culture and kindliness.

21. Himis is Imix, the name of the first day of the twenty-day month of the Maya calendar.

22. Hischen is Ix-Chel, the consort of Itzamna.

AND MONOGRAPHS 


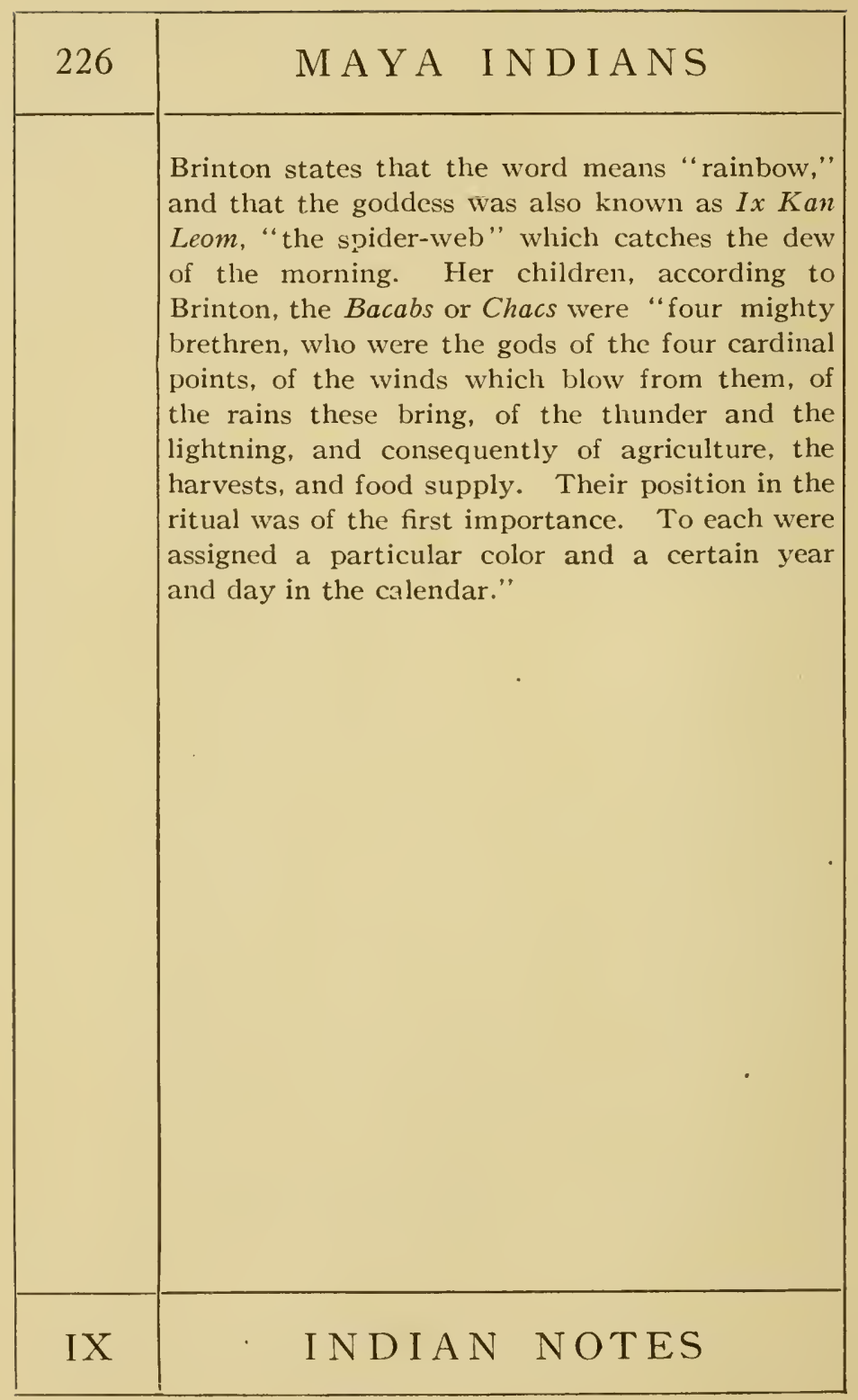






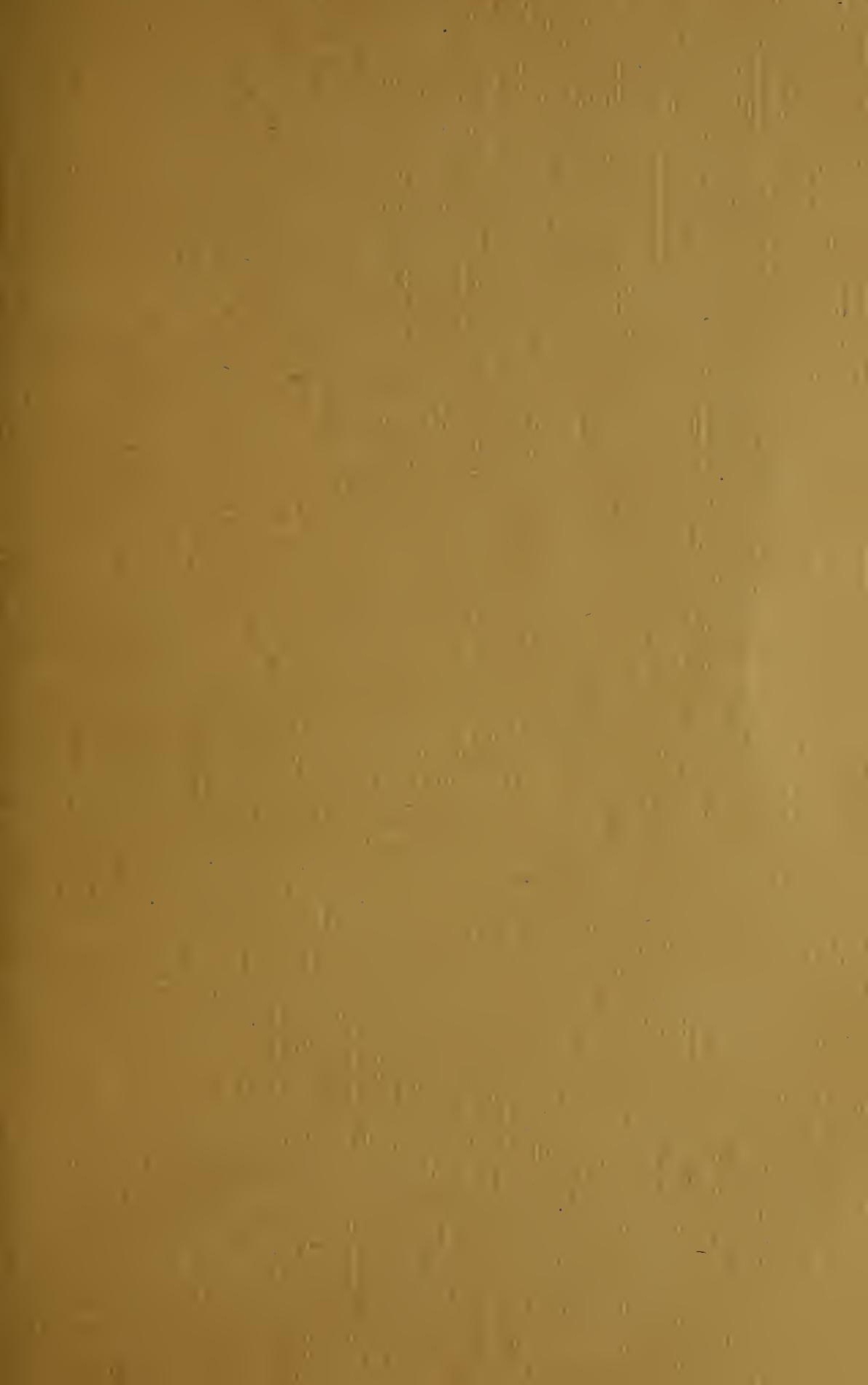


SMITHSONIAN INSTITUTION LIBRARIES

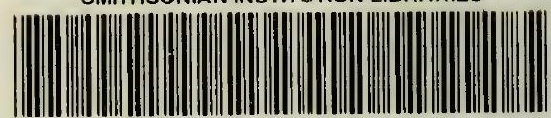

39088011534153 